Alma Mater Studiorum - Università di Bologna DEPARTMENT OF ECONOMICS

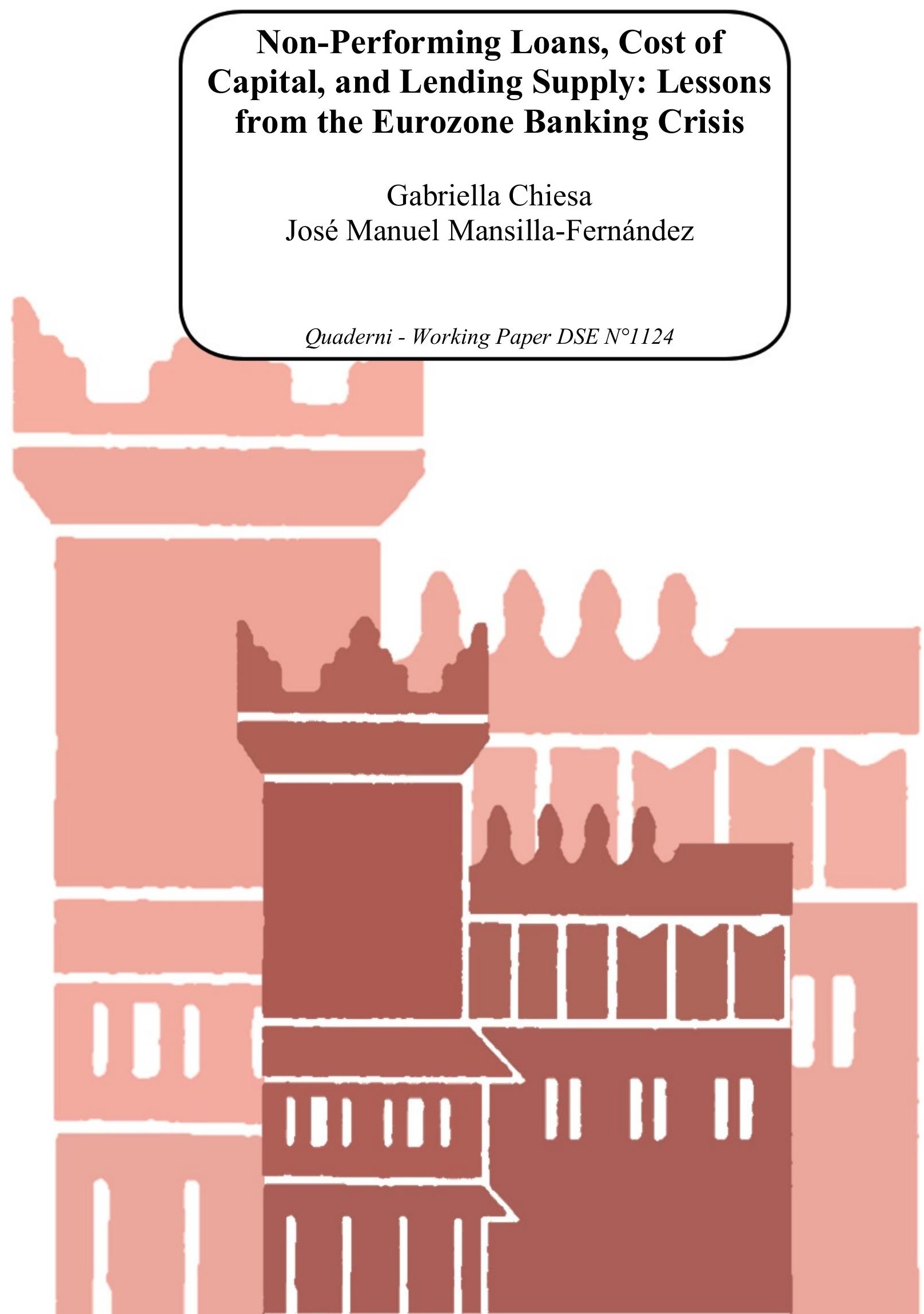




\title{
Non-Performing Loans, Cost of Capital, and Lending Supply: Lessons from the Eurozone Banking Crisis*
}

\author{
Gabriella Chiesa $^{\S} \quad$ José Manuel Mansilla-Fernández ${ }^{\dagger}$
}

\begin{abstract}
This paper develops a theoretical model as a foundation of empirical analysis of the transmission channel of non-performing loans (NPLs) on bank cost of capital, credit and liquidity creation in the Eurozone. Empirical results confirm the model's predictions and suggest that holding non-performing loans increases the cost of capital for banks in the short-term and the long-term. Moreover, the increased cost of capital reduces credit and liquidity creation, and the more so the less capitalized is the bank. This phenomenon is found to be economically more significant for European periphery country banks than for core country banks. The identification of the transmission channel is robust to the Granger predictability test.
\end{abstract}

Keywords: Cost of capital, credit supply, liquidity creation, NPLs, sovereign debt crisis.

JEL Classification: G11 G21 G32 H63

\footnotetext{
* Acknowledgements: We are very grateful to Giorgio Barba Navaretti, Giacomo Calzolari, and Alberto Franco Pozzolo for their invaluable guidance, advices, and encouragement. We are also indebted to Massimiliano Barbi, Santiago Carbó-Valverde, Paolo Manasse, Francisco Rodríguez-Fernández, Massimo Spisni, and seminar participants at the Department of Economics and the Department of Management of the University of Bologna for the helpful feedback and suggestions. All remaining errors are our own.

$\S$ Department of Economics, University of Bologna, Piazza Scaravilli 2, 40126 Bologna. Italy. E-mail: gabriella.chiesa@unibo.it

${ }^{\dagger}$ Department of Economics, Management, and Quantitative Methods, University of Milan, Via Conservatorio 7 , 20122 Milan. Italy. E-mail: jose.mansilla@unimi.it
} 


\section{Non-Technical Summary}

A key legacy of the 2008 economic crisis was the accumulation of non-performing loans (NPLs) in the banking industry operating in the Eurozone. The growth of impaired loans was comparatively sharper for banks operating in the Eurozone periphery countries than for banks in the Eurozone core countries. Bear in mind that NPLs can be treated as observable information since European banks usually release their balance sheets on regular basis. At the bank level, equity investors might well cast doubts on the viability of the bank's business model, on future profitability and assets values. Moreover, to the extent that NPLs' performance is driven by the state of the economy, that is by aggregate risk, investors will require relatively higher returns on equity investment in banks holding NPLs as a compensation for undiversifiable risk, implying that the greater the volume of NPLs the bank carries the higher its cost of capital. Bank capital serves as a buffer to absorb possible bank losses and avoid bankruptcy or simply restructuring processes. Indeed, a bank can control its default probability by limiting risk-taking, e.g., by restricting lending and liquidity creation, and/or by increasing capital via equity issuance.

We develop a theoretical model along these lines and use its predictions to address empirically two main questions. Firstly, we examine whether, as predicted by the theoretical model, NPLs foster equity investors' required returns and hence the bank's cost of capital. Secondly, we analyse whether the cost of capital impacts negatively on credit expansion and liquidity creation, and if these effects are exacerbated by shortage of bank capital. Our empirical results suggest that NPLs increase the cost of capital for banks both in the short-term and in the longterm, and this impacts negatively on lending and liquidity creation. Whilst previous research has focused on the deleterious impact of NPLs on book value of bank capital, to the best of our knowledge, this study is one of the first to analyse the impact of NPLs on bank cost of capital. Interestingly, we do find that bank leverage enhances the sensitivity of lending and liquidity 
creation to the bank's cost of capital, which means that the lending volume granted by banks endowed with relatively higher levels of capital is less affected by changes in investors' required return on bank equity holdings.

Importantly, taking into consideration that European periphery country banks accumulated comparatively greater levels of NPLs than European core country banks, we estimate separately the transmission channel for both 'Europes'. We find that this phenomenon is economically more significant for banks operating in the Eurozone periphery countries than for those in the Eurozone core countries.

The robustness of our results is validated by repeating the experiment for a sub-sample of German banks. Note the reader that German banks were commonly considered to be the safest ones in the Eurozone, because they held the lowest levels of NPLs compared to banks in other countries, and Germany has been more immune from macro/crisis shocks. Since we obtain qualitatively similar estimates for German banks, we draw the conclusion that our results are not driven by hidden common factors. Finally, the Granger predictability test confirms the uniqueness of the direction of the transmission channel. These results confirm the theoretical foundations of the transmission channel under investigation. 


\section{Introduction}

The level of non-performing loans (NPLs hereafter) were relatively stable until the beginning of the 2008 financial crisis. Afterwards, the quality of banks' portfolio has progressively declined. The response of national governments and central banks to deal with impaired bank assets, recapitalizing and / or restructuring troubled banks were significant in Europe and the United States (Avgouleas and Goodhart, 2015, 2016). At the time of writing this article, large stocks of NPLs on the banks' balance sheets continue to weight on profitability, to tie up bank capital, to raise funds and to threaten financial stability (Aiyar et al., 2017). The official statistics reveal that the problem of NPLs is concentrated in the so-called European periphery countries: in December 2016 Greek banks accumulated around 45.86 percent of NPLs over total gross loans, Portugal around the 19.52 percent, Italy around 15.30 percent, Ireland around 13.57 percent, and Spain around 5.71 percent (see, ESRB 2017; Mansilla-Fernández, 2017, pp. 33). At the bank level, large volume of NPLs could cast doubts on the viability of the bank's business model and its resilience on future downturns, thus increasing uncertainties about future profitability and asset values. Consequently, adverse market perceptions lead to increases in the cost of funding for the overall banking sector (ESRB, 2017). The core question of this study is whether NPLs impact on the cost of capital in the short-term and the long-term. The key observation is that NPLs performance is driven by the state of the economy, i.e. by aggregate risk, and investors require a compensation for aggregate/undiversifiable risk. We then extend the analysis by examining the effects of the cost of capital on lending supply and liquidity creation. This allows to enlighten the transmission channel of NPLs on credit and liquidity provision.

To perform our empirical analysis, we rely on a unique sample that contains the universe of the Eurozone listed banks from Bureau van Dijk's Bankscope and Orbis Bank Focus, and market information from Thomson Reuters Datastream, consisting in 225 listed banks for the 
period 2002Q1-2016Q4. We employ the NPLs ratio to measure the weight of impaired loans over the volume of granted loans at the bank level. Importantly, the cost of capital is measured as the market's required return on bank equity; a linear combination of the yield on the 10years bund, the bank's Beta CAPM and the expected risk premium (ERP hereafter). Following previous studies, we measure lending supply as the proportion of credit to customers over bank's total assets, whilst liquidity creation is computed following Berger and Bowman (2009) and Berger et al. (2016) methodology. We test the transmission channel by estimating an autoregressive distribution lags (ADL hereafter) model that allows us to assess the evolution of the impacts period-by-period towards the steady-state.

This article is related to the following three strands of the financial literature. The main question raised in this study is whether banks holding certain levels of NPLs might face higher cost of capital over time. So far, previous literature has analysed the causes of NPLs as a result of banks' under-capitalization and moral hazard issues. The current advances on banking regulation has considerably tightened the minimum capital requirements and the standard of provisioning expected credit losses for the recognition of impairments (IFRS-9 accounting rule). The role of bank's capital has been considered as a cornerstone of the standard theory on banking regulation since it decides the levels of lending that a bank could supply (Caprio and Summers, 1993; Calomiris and Jaremski, 2016). In particular, the so-called moral hazard hypothesis predicts that troubled bank's managers would be willing to increase the riskiness of their portfolio in a 'gamble to resurrection' (Berger and DeYoung, 1997). As a result, this strategy will be prone to grant credit to low-scored borrowers, and later on it will increase again the volume of NPLs (Bowman and Malmendier, 2015; Buchner and Wagner, 2017; Eisdorfer, 2008; Koudstaal and Wijnbergen, 2012; Schivardi et al., 2017). In other words, banks' quality portfolio may endogenously generate further risk-taking, since NPLs above a threshold may incentivize banks to shift risk (Bernanke and Gelter, 1986; Caballero et al., 2008; Peek and 
Rosengren, 2005). ${ }^{1}$ Nowadays, the literature is devoting growing attention to the repercussions of NPLs on banks' lending, and utterly on the real sector. We contribute to the existent literature by demonstrating that NPLs increase the cost of capital for banks both in the shortterm and in the long-term, and this impacts negatively on lending and liquidity creation. These results are robust to false positive / negative tests performed by repeating the experiment on the German listed banks. ${ }^{2}$ Whilst previous research has focused on the deleterious impact of NPLs on book value of bank capital, to the best of our knowledge, this study is one of the first to analyse the impact of NPLs on bank cost of capital.

In a second step, we investigate to what extent the cost of capital may affect liquidity creation (also called maturity transformation) and lending supply. Addressing this question is worthy of research. Following Basel III, banks planning to increase their credit basis are required to issue equity to meet the capitalization standards. Moreover, banks are concerned to limit the probability of bankruptcy, or simply of restructuring processes. Indeed, a bank can control its default probability by limiting risk-taking, e.g., by restricting lending and liquidity creation, and/or by increasing capital via equity issuance. If the cost of capital becomes relatively greater, the bank is expected not to generate neither new lending and nor transform maturity. ${ }^{3}$ Closely related to our paper, Accornero et al. (2017) demonstrate that NPLs follow a 'dynamic' transmission mechanism that affects the supply of credit. They find that

\footnotetext{
${ }^{1}$ Several authors advocate that bank size and the too-big-to-fail (TBTF hereafter) problem represents another channel through which banks may generate NPLs (Salas and Saurina, 2002; Stern and Feldman, 2004; Cai et al., 2018). In particular, TBTF banks may assume excessive levels of risk by taking advantage of their market power position since market disciple is not imposed by creditors. Accordingly, Louzis et al. (2012) show that the TBTF hypothesis is demonstrable depending on loan categories.

${ }^{2}$ We consider that the robustness of our results would be more powerful tested on the German listed banks, since they hold lower levels of NPLs than the others. Consequently, they are perceived as relatively safer banks than others headquartered in different countries. Note the reader that if the transmission channel is found to work in banking markets with low levels (and variations) of NPLs, the existence of the 'theoretical' mechanism might be demonstrated regardless the origin of the bank.

${ }^{3}$ Assessing the threshold from which high levels of NPLs become deleterious is still an open question. Zhang et al. (2016), for a sample of Chinese banks, demonstrate the existence of a threshold 'effect' of $4.81 \%$ in the NPLs ratio. They corroborate that banks holding ratios above this threshold will behave according to the moral hazard hypothesis, then suffering ulterior losses in the long-term.
} 
adjustments in the book value of capital (measured through the Asset Quality Review) have negative effects on bank lending, similarly to negative shocks to bank's capital buffers. In other words, increasing trends in NPLs have negative implications for capital buffers, which might lastly reduce credit supply (Berger and Bowman, 2013; Dagher et al., 2014; Van der Heuvel, 2008). ${ }^{4}$ By running the ADL estimator for the cost of capital, our results demonstrate that the increased cost of capital reduces lending supply and liquidity creation in the short-term and the long-term. Interestingly, we do find that bank leverage enhances the sensitivity of lending and liquidity creation to the bank cost of capital, which means that the lending volume granted by banks endowed with relatively higher levels of capital is less affected by changes in investors' required return on bank equity holdings.

Importantly, our analysis also takes into consideration possible endogeneity problems derived from adverse macroeconomic conditions (e.g., Angelini et al., 2017; Ghosh, 2017; Lakdawala et al., 2017) and the sovereign debt crisis, the so-called 'sovereign-bank nexus' (e.g., Altavilla et al., 2014; Buch et al., 2016; Li and Zinna, 2014; Podstawski and Velinov, 2018). ${ }^{5}$ In some countries, the crisis has been originated in banks, and afterwards transmitted to governments, the so-called 'Irish style' crisis. In others, sovereign finances have induced fragility in banks' balance sheet, the so-called 'Greek style' crisis. Overall, the crisis has threatened the solvency of the Eurozone banks via mark-to-market losses in European periphery sovereign bonds holdings. ${ }^{6}$ The Brunnermeier et al. (2011) seminal paper demonstrates that sovereign risk exposures are a source of financial instability for the banking

\footnotetext{
${ }^{4}$ Recent authors demonstrate that high levels of NPLs might deteriorate creditworthiness and reduce the demand for credit (Accornero et al., 2017; Balgova et al., 2016; Bending et al., 2014; Cuccinelli, 2015).

${ }^{5}$ The Kaminsky and Reinhart's (1999) seminal paper highlights that increasing levels of NPLs often arises as a consequence of banking crises, but both are the result of the economic downturns that dampen simultaneously the banking sector and the real economy.

${ }^{6}$ See Caporin et al. (2018), Paniagua et al. (2017) and Reusens and Croux (2017) for a profound exploration of the determinants of sovereign debt spread between periphery and core countries during the crisis. Additionally, Barba Navaretti et al. (2016) and Lanotte et al.(2016) discuss the lively debate about the regulatory implications of the sovereign-debt nexus.
} 
sector as a whole. One of the most important aftermaths of the crisis was the freezing of the interbank markets and the subsequent financial markets fragmentation, in which banks in the core countries were relatively less willing to lend to those headquartered in the European periphery countries. The consequences of the crisis were intensified because of interconnections amongst banks within the European banking system, the so-called 'sovereign credit risk channel' (Betz et al., 2016; Engle and Grobe, 2016; Gennaioli et al., 2014; Paltalidis et al., 2015). To control for possible endogeneity issues due to macroeconomic conditions, we instrument the NPLs ratio with GDP growth and the unemployment rate. Moreover, we break our sample down into banks operating in the core and the European periphery countries to test possible differences in the intensity of the transmission channel in both 'Europes'. As expected, our results suggest that the impact of NPLs on the cost of capital is relatively greater for banks operating in the European periphery countries than for those in the core countries in the shortterm and the long-term. Accordingly, we also do find that the transmission effect on liquidity and lending supply is relatively higher in the European periphery countries than in the core countries. Importantly, our findings corroborate the fragmentation of the Eurozone banking markets as a corollary of the NPLs crisis. ${ }^{7}$ Finally, our results are robust to the inclusion of the 10-year sovereign debt CDS as a control for the effects of the sovereign debt crisis on cost of capital, lending and liquidity supply.

The remainder of the paper proceeds as follows. Section 2 provides the theoretical model as a foundation to our empirical analysis. Section 3 presents the data and the empirical framework. Section 4 describes the main results. Section 5 concludes.

\footnotetext{
${ }^{7}$ See Anastasiou et al. (2017) for similar results.
} 


\section{Theoretical framework}

This section develops a theoretical model as a foundation to the subsequent empirical analysis.

Our framework builds on two basic facts. Banks' balance sheet decisions are strongly affected by value at risk (VAR) (e.g., Adrian and Shin, 2010). Second, loan performance is largely driven by the state of the economy, that is, by aggregate risk (e.g., BIS, 2005; Keenan, 2000; Angelini et al., 2017; Ghosh, 2017; Lakdawala et al., 2017).

We consider a bank that has inherited from the past legacy problematic loans (NPLs), debt raised to fund the legacy loans, and a capital (safe assets) endowment. The bank chooses lending volume and new equity issuance (capital increase) so as to maximize insiders' expected profits subject to a VAR constraint, loan demand constraint, and equity investors' participation constraints.

Let us define the state of the economy (aggregate risk) $\tilde{A}$ distributed over the interval $[\underline{A}, \bar{A}]$, with distribution function $F(A)$. The greater the realization of $\tilde{A}$, the better assets' returns. Let us now consider the following legacy variables. Legacy loans (NPLs), $n$, whose unit payoff is $\gamma \tilde{A}$; $\gamma$ represents the quality of loans, the lower $\gamma$ the worse the quality of legacy loans. Legacy debt resulting from the origination of legacy loans is defined as a function increasing in $n, D(n)$. Legacy safe assets is represented as $k$. Consequently, net assets $\left(k^{\prime}\right)$ is defined as the difference between legacy safe assets and legacy debt: $k^{\prime}(n)=k-D(n)$, which is decreasing in $n$.

New capital can be raised by new equity issuance, $s$. Investors providing capital to bank $i$ require a gross return equal to the safe gross rate of interest, $r_{f}$, plus the compensation for bank $i$ 's (undiversifiable) risk, i.e., the product of bank $i$ beta times the equity market risk premium (ERP). So, the return that investors require to provide capital to bank $i$ is:

$$
R_{i}=r_{f}+\beta_{i} E R P
$$


The larger the volume of NPLs held by the bank, the greater the bank's exposure to aggregate risk, the greater its beta and the greater investors' required return.

A new loan requires one unit of resources and generates a random return whose realization depends on aggregate risk. For simplicity, we assume that the unit random return is $\tilde{A}$ and a new loan is positive in net present value:

$$
E(\tilde{A})>1
$$

The bank funds lending, $x$, with deposits and capital, and by virtue of deposit insurance, depositors are rewarded at the unitary gross rate. The new debt issued by the bank is $x-(k+s)$, and the total amount of bank debt, $D(n)+x-(k+s)$ :

$$
x-\left(k^{\prime}(n)+s\right)
$$

The terminal value of the bank (i.e., the payoff of the bank's equity holders) is

$$
\tilde{\pi}=\max \left\{\tilde{A}(x+\gamma n)-\left[x-\left(k^{\prime}(n)+s\right)\right], 0\right\}
$$

The bank will default if the asset side realization, $\tilde{A}(x+\gamma n)$, falls below the repayment owed to depositors, $x-\left(k^{\prime}(n)+s\right)$, i.e., iff $A \leq \frac{x-\left(k^{\prime}(n)+s\right)}{x+\gamma n}$. The bank's default probability is then $F\left(A_{0}\right)$, being

$$
A_{0} \equiv \frac{x-\left(k^{\prime}(n)+s\right)}{x+\gamma n}
$$

increasing in new lending, $x$, and in legacy loans, $n$, and decreasing in legacy capital and new capital issuance $s \geq 0$.

The fraction of bank value accruing to the original shareholders will be $1-\alpha$, where $\alpha$ is the fraction accruing to the investors that provide new capital, $s$, and is such that $\alpha E(\tilde{\pi})$ equals the return required for providing risky capital $s$ :

$$
\alpha E(\tilde{\pi})=s R_{i}
$$

The cost of raising s units of new capital is then $\mathrm{c}(\mathrm{s})=s R_{i}$ :

$$
c(s)>s, c^{\prime}(s)>0 \text { and increasing in NPLs by (1) }
$$


The expected payoff to the original shareholders (insiders) is thus $E(\tilde{\pi})-c(s)$.

The bank acts in the interest of the original shareholders and chooses the volume of lending, $x$, and new equity issuance $s$ so as to maximize original shareholders' payoff, subject to a demand-feasibility constraints on lending, $x \leq x^{D}$, and the VAR constraint that the bank default probability does not exceed a threshold level $v$, that is $F\left(\frac{x-\left(k^{\prime}(n)+s\right)}{x+\gamma n}\right) \leq v$.

The bank's optimization problem is then:

$$
\max _{x, s>0} \int_{A_{0}}\left\{A(x+\gamma n)-\left[x-\left(k^{\prime}(n)+s\right)\right]\right\} d F(A)-c(s)
$$

s.t.

- VAR constraint: $F\left(\frac{x-\left(k^{\prime}(n)+s\right)}{x+\gamma n}\right) \leq v$

- Demand constraint: $x \leq x^{D}$

The VAR constraint amounts to a floor on the solvency probability (a ceiling to the bankruptcy probability). The VAR constraint sets a limit to bank lending $x^{V A R}$ increasing in bank net capital (capital endowment less legacy debt), $k^{\prime}(n)$, and new equity issuance $s$, and decreasing in the volume $n$ of NPLs, and the more so the lower NPLs' quality $\gamma$

$$
\begin{gathered}
x \leq x^{V A R}\left(k^{\prime}, s, \gamma n\right) \\
\frac{\partial x^{V A R}}{\partial k^{\prime}}>0, \frac{\partial x^{V A R}}{\partial s}>0, \frac{\partial x^{V A R}}{\partial N P L}<0
\end{gathered}
$$

Equation (2) express that NPLs reduce the volume of lending that satisfies the VAR constraint via two main channels. One is the capital channel: The greater the legacy loans, the greater legacy debt, and the lower net capital. The other is the risk channel. There is ample evidence that NPLs performance largely depends on the state of the economy, downturn versus upturn (e.g., Angelini et al., 2017; Ghosh, 2017; Lakdawala et al., 2017), that is, NPLs' performance depends on aggregate risk and thereby NPLs risk is positively correlated with new loans' risk. 
At an optimum, necessarily either the VAR constraint or the demand constraint is binding:

$$
x \leq \min \left(x^{V A R}, x^{D}\right)
$$

and if the VAR constraint is binding, new equity issuance can be positive depending on the cost of capital. The lower capital and the greater NPLs, the lower $x^{V A R}$, the more likely that the VAR constraint binds, and therefore that the bank cost of capital is a determinant of bank lending.

The analysis suggests:

Hypothesis 1 (Cost of capital): A positive impact of NPLs on the bank's cost of capital.

Hypothesis 2 (Credit supply): A negative impact of the cost of capital on credit supply, and the more so the less capitalized is the bank

To the extent that bank loans have longer maturity than bank debt (deposits), i.e., banks engage in maturity transformation and thereby in liquidity creation:

Hypothesis 3 (Liquidity creation): A negative impact of the cost of capital on liquidity creation.

We will examine whether these conjectures are validated by the data and the extent to which there is persistence.

\section{Data and empirical framework}

\subsection{Data and sample selection}

We rely on bank balance sheet information provided by Bureau van Dijk's Bankscope and Orbis Bank Focus databases. The dataset consists in quarterly information for a sample of Eurozone banks for the 2002Q1-2016Q4 period. $^{8}$ We initially include consolidated balance

\footnotetext{
${ }^{8}$ The Eurozone Members included in our sample are Austria, Belgium, Cyprus, Estonia, Finland, France, Germany, Greece, Ireland, Italy, Latvia, Lithuania, Luxembourg, Malta, Netherlands, Portugal, Slovakia, Slovenia, and Spain.
} 
sheets and income statements of commercial banks, savings banks, and credit unions for banks operating in the Eurozone countries. All the banks included in our database display information following and accounting period running from the $1^{\text {st }}$ of January until $31^{\text {st }}$ of December. Since the above-mentioned databases allow us to identify the listed banks, we extract all the institutions within this category. To remove ambiguity and double counting of firms, banks were selected at the highest corporate level possible, usually as holding companies. The final sample includes 225 listed banks.

We consider that the years selected to perform this study are relevant since we are including the period before the financial crisis in which banks were granting the highest volume of credit and taking more risk (2002Q1-2007Q2), and the period that encompass the banking and the sovereign debt crises (2007Q3-2016Q4).

Data are expressed in thousands of euros and are inflation adjusted. We also removed nonconsistent values such as zero total assets, negative equity values, and zero employees. Finally, we obtain a sample of 2,400 panel data for all sample years.

Since the relevant stock market portfolio is the Eurozone market portfolio, we use the EURO STOXX Index to compute market returns. Information about equity prices at the bank- and market level, and sovereign credit risk is retrieved from Thomson Reuters Datastream.

We acquired monthly times series for each listed bank, the EURO STOXX index from January 1990 until December 2016 in order to take into consideration enough period window when estimating risk measures and expected returns. Data from sovereign Credit Default Swaps (hereafter CDS) has also been reached from the same database. Similarly, Thomsom Reuters Datastream provides information about sovereign CDS from 2008 onwards. Besides, we retrieved information on GDP and unemployment rate from Eurostat. Later on, we merge handly bank information into the main database, and the macroeconomic variables automatically through the period variable for each country. 
Table 1 contains the definition of the variables employed in this article. We control for outliers in banking ratios since they might distort the estimations (see Adrian et al., 2015).

\subsection{Measuring the cost of capital: The CAPM model}

Bank cost of capital is given by the return that investors require to hold bank equity. We approximate the cost of capital with the standard CAPM model. Accordingly, investors' required return equals the safe gross rate of interest plus the compensation for bank $i$ 's (undiversifiable) risk, i.e., the product of bank $i$ beta times the equity market risk premium (ERP). ${ }^{9}$ Bank cost of capital, i.e., investors' required return on bank equity, at date $\mathrm{t}$ is $r_{i t}$ :

$$
r_{i t}=R_{t}^{f}+\beta_{i t} E R P_{t}
$$

We take as the risk-free rate $\left(R_{t}^{f}\right)$ the yield on the 10-year bund (German sovereign bond), since this maturity matches the shareholders' investment horizon.

The variable of interest is $\beta_{i t}$, known as the CAPM beta, it measures the covariance of the return of stock $i\left(R_{i}\right)$ with the return of the market portfolio $\left(R_{m}\right)$, over the variance of the market portfolio return:

$$
\beta_{i t}=\frac{\operatorname{Cov}\left(R_{i}, R_{m}\right)}{\operatorname{Var}\left(R_{m}\right)}
$$

Following Fama and MacBeth (1973) methodology, we estimate time-varying betas $\left(\beta_{i t}\right)$ using a rolling-window OLS regression for each bank $i$ with a window length equal to 24 months (two years) since betas may change substantially over time. ${ }^{10}$ We approximate the equity market risk premium at date $t, E R P_{t}$, with the historical mean of the realized EURO STOXX returns in excess of the contemporaneous 10-year bund yield over the past 60 months

\footnotetext{
${ }^{9}$ See King (2009) for a similar approach.

${ }^{10}$ Assuming constant betas for 5-years periods would be justified if betas were changing snail enough as in the case of diversified portfolios. Since new information is incorporated following the banking and the sovereign debt crises, for individual stocks, betas may change rapidly and the assumption of a window of 5-years period may be unsuitable.
} 
(five years) of observations, beginning in January 1990. This procedure allows us to obtain estimations from 2002 until 2016. The bank specific equity premium at date $t$ then equals the product of its CAPM Beta and the equity market risk premium at date $\mathrm{t}, \beta_{i t}\left(E R P_{t}\right)$.

\subsection{Measuring liquidity creation}

We calculate bank's $i$ liquidity creation $\left(L C_{i t}\right)$ in thousand euros following Berger and Bowman (2009) and Berger et al. (2016) three steps methodology on US banks. The components of $L C_{i t}$ are listed in Appendix A.3:

$$
\begin{aligned}
L C_{i t} & =0.5 \times \text { illiquid assets }+0.5 \times \text { liquid liabilities } \\
& -0.5 \times \text { liquid assets }-0.5 \times \text { illiquid liabilities } \\
& -0.5 \times \text { equity }
\end{aligned}
$$

The interpretation of this indicator proceeds as follows. Banks create liquidity on the balance sheet when they transform illiquid assets into liquid assets. In other words, banks hold illiquid items and give the public the liquid ones. Thus, positive sign is applied to both illiquid assets and liquid liabilities, so when liquid liabilities are used to finance illiquid assets, liquidity is created. Following a similar reasoning, negative sign is applied to liquid assets, illiquid liabilities and equity, so when illiquid liabilities or equity are employed to finance a euro of liquid assets, liquidity is reduced. The negative sign on equity captures the direct effect of capital on the process of liquidity creation. The magnitudes of the weights are based on the euro-for-euro adding-up constraints, so that 1 euro of liquidity is created (destroyed) when banks transform 1 euro of illiquid (liquid) assets into 1 euro of liquid (illiquid) assets. Based on this constraint, a weight of $1 / 2$ is assigned to illiquid assets and liquid liabilities, and $-1 / 2$ to liquid assets, illiquid liabilities and equity. Therefore, when one euro of liquid liabilities finances one euro of illiquid assets liquidity creation equals: $1 / 2 \times 1$ EUR $+1 / 2 \times 1$ EUR $=1$ EUR. The weight of $1 / 2$ applied to illiquid assets and liquid liabilities, since the volume of liquidity created if only "half" determined by the use of funds, which are needed to generate 
liquidity. The same reasoning is applied when 1 euro of illiquid liabilities or equity is used to finance 1 EUR of liquid assets $(-1 / 2 \times 1$ EUR $-1 / 2 \times 1$ EUR $=1$ EUR). In this case, 1 EUR of liquidity is destroyed (see Berger and Bowman, 2009).

\subsection{Testing for cointegration}

\section{The Augmented Dickey Fuller test}

We use panel data that consists of both time series and cross-section information. Regarding time series information, we use the Augmented Dickey Fuller (ADF hereafter) test to assess whether time series are affected by transitory or permanent shocks (Dickey and Fuller, 1979, 1981). The financial crisis may incorporate a structural break that would have affected the cost of capital and bank performance. In the presence of a structural break, the standard ADF test is biased towards the non-rejection of the null hypothesis. We follow the Perron's (1989) methodology that includes the single exogenous shock (known) break according to the underlying asymptotic theory by using a modified ADL model. Thus, we test for unit root in market and bank variables by using the following three equations:

$$
\begin{gathered}
z_{i t}=\theta_{10}+\theta_{11} z_{i, t-1}+\theta_{12} D T_{t}+\theta_{13} t+\sum_{i=1}^{L} \vartheta_{1 i} \Delta z_{i, t-i}+e_{i t} \\
z_{i t}=\theta_{20}+\theta_{21} z_{i, t-1}+\theta_{23} t+\theta_{24} T_{t}+\theta_{25} B T_{t}+\sum_{i=1}^{L} \vartheta_{2 i} \Delta z_{i, t-i}+e_{i t} \\
z_{i t}=\theta_{30}+\theta_{31} z_{i, t-1}+\theta_{32} D T_{t}+\theta_{33} t+\theta_{34} T_{t}+\theta_{35} B T_{t}+\sum_{i=1}^{L} \vartheta_{3 i} \Delta z_{i, t-i}+e_{i t}
\end{gathered}
$$

where $z_{i t}$ represents the variables to be tested corresponding to the following indicators. Firstly, we introduce the cost of capital $\left(r_{i t}\right)$, or expected return on equity, as computed in expression (3). Secondly, we employ the CAPM beta $\left(\beta_{i t}\right)$ as shown in expression (4). Thirdly, we 
calculate the bank's $i$ book-value return on equity $\left(R O E_{i t}\right)$ defined as the ratio profit (losses) before taxes over total equity. We also include the gap between the expected cost of capital and ROE $\left(r_{i t}-R O E_{i t}\right)$. Finally, we include the non-performing loans defined as the volume of non-performing loans over total loans to customers.

The time variables proceed as follows. The variable $T_{t}$ represents changes in levels and takes the one if $t=2007 \mathrm{Q} 3$, and zero otherwise. The slope dummy $D T_{t}$ represents the change in the trend of the slope function and takes the value one if $t<200 \mathrm{Q} 3$ and zero otherwise. The crisis dummy $B T_{t}$ controls for changes produced after the beginning of the financial crisis and takes the value one if $t>2007 \mathrm{Q} 3$, and zero otherwise. Each of the three models has a unit root with a structural break under the null hypothesis, as the dummy variables are integrated in the system. The alternative hypothesis is a broken trend stationary process.

\section{The Johansen-Fisher cointegration test for panel data}

The cointegration presented in this study follows the Johansen-Fisher test proposed by Maddala and $\mathrm{Wu}$ (1999). This procedure is a panel version of the individual Johansen (1988) cointegration test based on the fundamentals of the Fisher ADL panel unit root test. The Johansen-Fisher cointegration test adds the $p$-values of the Johansen individual eigenvectors and trace statistics. The following statistical test is derived:

$$
\lambda=-2 \sum_{i=1}^{N} \log \left(\pi_{i}\right) \sim \chi_{2 N}^{2}
$$

where $\pi_{i}$ is the $\mathrm{p}$-value of from an individual cross-section $i \ldots N$, under the null hypothesis of no cointegration for panel data.

\subsection{Empirical approach}


This section discusses the identification strategy to estimate the impact of NPLs on the cost of capital, the difference between the cost of capital and bank's performance, and market risk over time besides the steady state. ${ }^{11}$

Our empirical strategy is based on the following autoregressive distributed lags (hereafter ADL) model with structural break as follows: ${ }^{12}$

$$
r_{i t}=\alpha_{0}+\alpha_{1} r_{i t-1}+\alpha_{2} N P L_{i t}+\alpha_{3} N P L_{i, t-1}+X_{i, t-1}^{\prime} \Phi+v_{i}+u_{i t}
$$

where the variable $r_{i t}$ is bank $i$ cost of capital. Regarding the explanatory variables, the variable of interest is $N P L_{i t}$ that represents the non-performing loans ratio as defined in Table 1 , and the lagged value of the cost of capital $\left(r_{i, t-1}\right)$. The matrix $X_{i, t-1}^{\prime}$ is a set of control variables that includes the following variables. The bank leverage ratio $\left(L E V_{i, t-1}\right)$ is measured as total assets over total equity. The variable $L O A N T A_{i, t-1}$ is computed as the ratio loans to customers over total assets and represents the level of risk that the bank is able to run. The variable Size $_{i, t-1}$ is calculated as the natural logarithm of total assets and controls for firm size. The Lerner index (Lerner $_{i, t-1}$ ) controls for the degree of competition and is calculated as the difference between the price and the marginal costs, divided by the price (see Appendix A.1). The income structure ratio $\left(I N C_{i, t-1}\right)$ is computed as non-interest income to total assets and controls for business diversification. The efficiency ratio $\left(E F F_{i, t-1}\right)$ is calculated as operating costs over gross income. We control for the structural break after the beginning of the financial crisis by including the dummy variable Crisis $_{t}$ and takes the value one if $t \geq 2007 \mathrm{Q} 3$, and zero otherwise. Finally, we control for the effects of the sovereign debt crisis on the dependent variables by including the 10-years sovereign $\operatorname{CDS}\left(C D S_{h t}\right)$ for the home country of each bank.

\footnotetext{
${ }^{11}$ See Carbó-Valverde et al. (2017) for a similar approach.

${ }^{12}$ Note that the ADL model is equivalent to the error-correction mechanism by substituting $y_{i t}=y_{i, t-1}+\Delta y_{i t}$ and $N P L_{i t}=N P L_{i, t-1}+\triangle N P L_{i t}$. In the error correction mechanism, the adjustment of y towards the equilibrium is defined by the deviations of both variables one-period-lagged: $y_{i, t-1}-\frac{\alpha_{2}+\alpha_{3}}{1-\alpha_{1}} N P L_{i, t-1}$.
} 
As for the interpretation of expression (8), the ADL allows us to test whether the relationship between $N P L_{i t}$ and the indicators included in $r_{i t}$ are actually dynamic (i.e., $H_{0}: \alpha_{1}=\alpha_{3}=0$ ) and to assess the contemporaneous effect, or short-term effect, (i.e., $H_{0}: \alpha_{2}=0$ ). Furthermore, if the former hypotheses are rejected, the steady state can be estimated as follows:

$$
\gamma=\frac{\alpha_{2}+\alpha_{3}}{1-\alpha_{1}} \text { if }\left|\alpha_{1}\right|<1
$$

where $\left|\alpha_{1}\right|<1$ is the necessary and sufficient condition for the existence of globally asymptotically 'stable' solution. ${ }^{13}$ Finally, if the null $\left(H_{0}: \gamma=0\right)$ is rejected, we can draw the conclusion that there is a long-term equilibrium.

The second step of this research tests the effects of the cost of capital on credit supply and liquidity creation. Since the consequences of holding NPLs in the balance sheet are transmitted to the banking markets as a higher cost of capital, we repeat the procedure proposed before to assess whether the increase in the cost of capital has an impact on credit supply and liquidity creation in the short-term and the long-term. Then, we propose the following ADL specification:

$$
\operatorname{LOANTA}_{i t}=\delta_{0}+\delta_{1} \text { LOANTA }_{i t-1}+\delta_{2} r_{i t}+\delta_{3} r_{i t-1}+X_{i, t-1}^{\prime} \Omega+v_{i}^{\prime}+u_{i t}^{\prime}
$$

All the variables and subscripts are defined above. The transmission of the cost of capital to credit supply is expected to be negative in the short-term and the long-term (i.e., $\delta_{2}$ and $\delta_{3}<0$, and $\left|\delta_{1}\right|<1$ ). Finally, we are also interested in analysing whether the cost of capital have repercussions on banks' capacity to generate liquidity. According to the reasoning exposed above, we propose the following ADL model:

$$
\frac{L C_{i t}}{T A_{i t}}=\delta_{0}^{\prime}+\delta_{1}^{\prime}\left(\frac{L C_{i t-1}}{T A_{i t-1}}\right)+\delta_{2}^{\prime} r_{i t}+\delta_{3}^{\prime} r_{i t-1}+X_{i, t-1}^{\prime} \Lambda+v^{\prime \prime}{ }_{i}+u^{\prime \prime}{ }_{i t}
$$

\footnotetext{
${ }^{13}$ Two further solutions are possible. The unstable solution or hysteresis $(\alpha=1)$ means that the solution contains a linear trend and that the initial condition exerts full influence on $y_{i t}$. The explosive solution $(|\alpha|>1)$ is the contrary of the 'stable' solution, i.e., the effect of the regressor is divergent on $y_{i t}$.
} 
where $L C_{i t}$ represents liquidity creation as defined in expression (5), and all the variables and subscripts are defined above.

\subsection{Testing for reverse causality: The Granger predictability test}

We use the Granger predictability test to assess the direction of the causality between NPLs and our variables of study: the cost of capital, CAPM beta, ROE and the gap between the cost of capital and ROE. We employ four lags $(l)$ of the variables in order to capture the long-term effects of NPLs on the target variables. Since we are using panel data, we follow the HoltzEaking et al.'s (1988) methodology with individual fixed effects $\left(f_{i}\right)$. The statistical significance of the test is measured by using an $F$-test.

In order to test whether NPLs predict our variables of study, two conditions should be meet:

i) The NPLs ratio $\left(N P L_{i t}\right)$ should be statistically significant to the cost of capital $\left(r_{i t}\right)$ :

$$
r_{i t}=\varphi_{0}+\sum_{l=1}^{L} \varphi_{l} r_{i, t-l}+\sum_{l=1}^{L} \psi_{l} N P L_{i, t-l}+v_{t}+f_{i}+\varepsilon_{i t}
$$

ii) The cost of capital $\left(r_{i t}\right)$ should not be significant in explaining NPLs $\left(N P L_{i t}\right)$ :

$$
N P L_{i t}=\varphi_{0}^{\prime}+\sum_{l=1}^{L} \varphi_{l}^{\prime} r_{i, t-l}+\sum_{l=1}^{L} \psi_{l}^{\prime} N P L_{i, t-l}+v_{t}+f_{i}+\varepsilon_{i t}^{\prime}
$$

\section{Results}

\subsection{Summary statistics and parametric and non-parametric tests}

Table 2 shows the summary statistics of the variables employed in this study. In Panel A, we observe that banks' cost of capital $\left(r_{i t}\right)$ has a mean value of 16.09 percent ranging from 8.02 percent to 30.78 percent, while banks' profitability gap $\left(r_{i t}-R O E_{i t}\right)$ has a mean value of 12.36 percent ranging from 0.01 percent to 55.28 percent. Regarding the components of the cost of capital, banks' risk, measured as the CAPM beta $\left(\beta_{i t}\right)$, has a mean value of 1.77 ranging from 
1.03 to 2.89 , and the equity market risk premium $\left(E R P_{t}\right)$ displays a mean value of 7.10 percent ranging from 3.33 percent to 12.39 percent. The non-performing loans ratio $\left(N P L_{i t}\right)$ is the variable of interest, displaying a mean value of 8.46 percent ranging from 0.63 percent to 47.85 percent. Furthermore, leverage ratio $\left(L E V_{i t}\right)$ displays a mean value of 16.36 ranging from 4.36 to 46.54. Regarding lending and liquidity supply variables, the ratio loans to customers to total assets $\left(L O A N T A_{i t}\right)$ shows a mean value of 0.59 ranging from 0.06 to 0.88 , and the ratio liquidity creation to total assets $\left(L C_{i t} / T A_{i t}\right)$ has a mean value of 0.32 ranging from -0.46 to 1.02 . Finally,

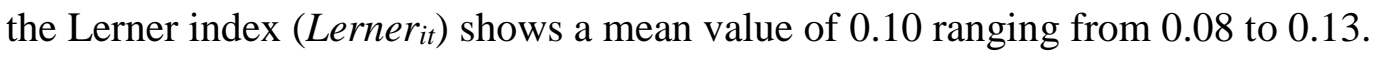

We perform a mean-difference test, as shown in Panel B. In the first step, we create the dummy variable Crisist which takes the vale one from 2007Q3 onwards, and zero otherwise, to split the sample into two subperiods: before (2002Q1-2007Q2) and after (2007Q3-2016Q4) the banking crisis to test whether the crisis supposed a structural break. We find that the parametric test rejects the null $\left(H_{0}\right.$ : Crisist $(0)-$ Crisis $\left._{t}(1)=0\right)$ for all the variables and, barely for bank size $\left(\right.$ size $\left._{i t}\right)$. The results confirm that the alternative hypothesis $\left(\mathrm{H}_{0}\right.$ : Crisis $(0)-\mathrm{Crisis}_{t}$ $(1)<0)$ is confirmed for banks' risk $\left(\beta_{i t}\right)$, the cost of capital $\left(r_{i t}\right)$, and profitability gap $\left(r_{i t}-\right.$ $R O E_{i t}$ ), thus indicating that banks were perceived as riskier institutions after the crisis as expected, thus increasing their cost of capital as expected. Therefore, the alternative hypothesis is also confirmed for the non-performing loans ratio $\left(N P L_{i t}\right)$ which confirms its growth path as a consequence of the crisis. Importantly, we also find that the levels of bank size (size $\left.e_{i t}\right)$ credit supply $\left(L O A N T A_{i t}\right)$ and liquidity creation $\left(L C_{i t} / T A_{i t}\right)$ are significantly higher after the crisis, reflecting some extent of inertia of these variables after the crisis. The other variables of interest are the book-value return on equity $\left(R O E_{i t}\right)$ and the leverage ratio $\left(L E V_{i t}\right)$ which are found to be higher before the crisis $\left(H_{0}\right.$ : Crisist $(0)-$ Crisist $\left._{t}(1)>0\right)$.

To complement the results presented above, we perform a parametric test for comparison of means distinguishing between core and European periphery countries, for the whole period 
(2002Q1-2016Q4), the time period before the crisis (2002Q1-2007Q2) and after the crisis (2007Q3-2016Q4), as shown in Table 3. We show that the parametric test rejects the null hypothesis $\left(H_{0}\right.$ : Core $(0)$ - Periphery $\left.(1)=0\right)$ for the non-performing loans ratio $\left(N P L_{i t}\right)$ for the whole period. Specifically, the test rejects the null hypothesis for the crisis period. Similarly, the null hypothesis is rejected for the Beta CAPM $\left(\beta_{i t}\right)$ for both subperiods, indicating that banks operating in European periphery countries are perceived as riskier than those located in the core countries. Accordingly, we find similar results for the cost of capital $\left(r_{i t}\right)$ and profitability gap $\left(r_{i t}-R O E_{i t}\right)$. Moreover, the difference between the European periphery and core countries banks with regard to their Beta CAPM, cost of capital and profitability gap is more pronounced after the crisis. Subfigure 1.a shows that the evolution of the NPLs ratio $\left(N P L_{i t}\right)$ dramatically split in the last years of the crisis, in particular because the volume of NPLs soars in the European periphery countries. Similarly, Subfigure 1.b shows that Beta CAPM $\left(\beta_{i t}\right)$ accompanied the evolution of the NPLs ratio, reflecting that markets effectively perceive banks with high levels of NPLs as risky institutions. Furthermore, Subfigure 1.c and Subfigure 1.d which illustrate the evolution of the cost of capital $\left(r_{i t}\right)$ and profitability gap $\left(r_{i t}\right.$ $\left.-R O E_{i t}\right)$ respectively, show that profitability required from banks is significantly larger in countries with high levels of $N P L_{i t}$.

\section{[Insert Figure 1 over here]}

Figure 2 displays the distribution functions of the variable of interests. Subfigure 2.a shows that the dispersion of NPLs ratio is higher for the European periphery countries than for the core countries, being the difference in dispersion even greater after the crisis. These results are consistent with the distributions of the Beta CAPM shown in Subfigure 2.b. The median values and the dispersion of Beta CAPM are higher for the European periphery countries than the core countries for both periods. Accordingly, the values for the cost of capital $\left(r_{i t}\right)$ and the profitability gap 
$\left(r_{i t}-R O E_{i t}\right)$ shown in Subfigures 2.c and 2.d, respectively, indicate that the cost of capital is higher for the banks operating in the European periphery countries than for those in the core countries.

\section{[Insert Figure 2 over here]}

Table 4 reports the mean values of the key variables divided in four quartiles of the nonperforming loans ratio $\left(N P L_{i t}\right)$. The test shows, for the whole sample, that the Beta CAPM $\left(\beta_{i t}\right)$ ranges from 1.84 in the first quartile to 2.23 in the fourth quartile. Accordingly, the cost of capital $\left(r_{i t}\right)$ also displays a growing path ranging from 0.15 in the first quartile to 0.21 in the fourth quartile indicating that investors claim for higher returns when banks hold higher levels of NPLs in their balance sheets. On the other hand, the book-value return on equity $\left(R O E_{i t}\right)$ shows a decreasing pattern insofar as the level of NPLs increases, becoming even negative in the fourth quartile. Consequently, the profitability gap $\left(r_{i t}-R O E_{i t}\right)$ diverge, ranging from 0.13 in the first quartile to 0.28 in the fourth quartile. Finally, the $F$-overall test rejects the null hypothesis that risk and cost of capital measures are independent of the fourth quartiles of NPLs ratio $\left(H_{0}: \gamma_{\mathrm{n}-q u a r t i l e}=0\right)$, which support the hypotheses that the amount of risk that banks accumulate in their balance sheets in form of NPLs is perceived by investors who utterly claim for higher returns.

\subsection{Short-term effect and long-term analysis of non-performing loans}

Before analysing the effects of non-performing loans on the cost of capital, we should test the existence of unit roots in the single variables, and cointegration between the interest variables taking into consideration the structural break. Panel A of Table 5 shows the results of the ADF test before the financial crisis (6.a), after the financial crisis (6.b), and during the whole period (6.c). The results reject the null hypothesis of unit roots at the 1 percent level and the 5 percent 
level. Panel B of Table 5 displays the results of the Johansen-Fisher test for panel cointegration tests. The trace tests indicate that two cointegration exist before and after the financial crisis.

The first question to be answer on this research is whether NPLs foster the banks' cost of capital in the short-term and the long-term (H-1). The estimations of the expression (8) are shown in Panel A of Table 6 by using the Arellano and Bond (1991) GMM estimator. Two-, three- and four-period-lagged instrumental variables are used as instrument to control for problems of endogeneity derived from correlations of errors over time. ${ }^{14}$ The results suggest that a one-standard-deviation-increase in the $N P L_{i t}$ increases the cost of capital by 0.06 standard deviations on average in the short-term for the Eurozone banks. Furthermore, we also find for the European periphery countries that one-standard-deviation-increase in NPLs ratio increases the cost of capital by 0.07 standard deviations in the short-term, whilst the increase is significantly lower for the core countries, 0.04 standard deviations. The results remain qualitatively stable and significant after including control variables $\left(H_{0}: \alpha_{2}=0\right)$. Furthermore, the $\alpha_{3}$ estimates for expression (8), which are positive, significant and lower than $\alpha_{2}$, indicates that the cost of capital still growths in the subsequent periods towards a convergent equilibrium. Accurately, a one-standard-deviation increase in the NPLs ratio augments the cost of capital by 0.19 percent $(p$-value $<0.000$ ) in the long-term for the banks in the Eurozone. Moreover, we also find that the long-term effect is higher for the banks operating in the European periphery countries than in the core countries. In this regard, we find that one-standarddeviation increase in the NPLs ratio augment by 0.28 percent $(p$-value $<0.000)$ the cost of capital for banks headquartered in the European periphery countries, whilst the impact for banks located in the core countries equals 0.14 percent $(p$-value $<0.000)$, lower than the former group. Taken together, the results of this study suggest that the cost of capital is more sensible

\footnotetext{
${ }^{14}$ Sargan test and serial autocorrelation test of second $(A R(2))$ and third order $(A R(3))$ are introduced to test the orthogonality of the instruments.
} 
for banks headquartered in European periphery countries than in core countries. The results remain robust after including control variables in the regressions. In Panel B of Table 6, we substitute Crisis $_{t}$ for the 10-year sovereign bonds CDS $\left(C D S_{h t}\right)$ in order to control for the effects of the sovereign debt crisis on the cost of capital. Accordingly, $C D S_{h t}$ is positive and significant, thus suggesting that the sovereign debt crisis was a source of increase in the cost of capital. Moreover, the results remain qualitatively stable for the variables of interest, thus suggesting the robustness of the results. These results confirm the first hypothesis of this study. The standard Sargan test and the autocorrelation tests $(A R(2)$ and $A R(3))$ demonstrate the orthogonality of the instruments employed in the regressions.

\subsection{The effects of the cost of capital on credit supply}

The first research question of this study is whether increases in the cost of capital are translated to the supply of credit. The estimations of the expression (10) are shown in Panel A of Table 7. Using an Arellano-Bond GMM estimator, we test the effects of the cost of capital on credit supply (H-2). Two-, three-, and four-legged values of the explanatory variable are used as instruments. The estimation of the parameter $\delta_{2}$ indicates that one-standard deviation increase in the cost of capital reduces the supply of credit by 0.03 percent for the Eurozone banks in the short-term. We also observe that one-standard-deviation increase in $r_{t}$ reduces LOANTA $A_{i t}$ by 0.04 and 0.03 for banks operating in the European periphery and the core countries, respectively. Our results suggest that that the supply of credit is more sensible to variations in the cost of capital for banks operating in the European periphery countries than for those in the core countries. The results are robust after including control variables. Importantly, we are also interested in analysing the repercussions of bank leverage $\left(L E V_{i t}\right)$ on credit supply. In other words, we investigate whether the difference found in both groups of banks might be driven by differences in leverage. On the one hand, we observe that banks in the European periphery 
countries holds a significant lower level of leverage than those headquartered in the core countries. Despite the reduction in this variable for the core countries banks after the beginning of the crisis, the difference between both groups is still significant for this period. On the other hand, the estimates indicate that banks headquartered in the European periphery countries are more sensible to variations in leverage than the core country banks. Moreover, the estimates for the interaction variables $L E V_{i t} \times r_{i t}$ and $L E V_{i t} \times r_{i t-1}$ are negative and significant, revealing that leverage enhances the sensitivity of lending to changes in the bank cost of capital.

Regarding the long-term, the results reject the null for hypothesis for the cost of capital $\left(H_{0}\right.$ : $\left.\delta_{2}=\delta_{3}=0\right)$, and the null for the adjustment parameter $\left(H_{0}: \delta_{1}=0\right.$ and $\left.\delta_{1}=1\right)$. We also find that the estimation for the parameter $\delta_{3}$ is negative, significant and lower than $\delta_{2}$ indicating that, in the long-term, a one-standard-deviation increase in the cost of capital $\left(r_{i t}\right)$ reduces lending supply by 0.10 percent for the Eurozone banks. In addition, we also find that banks in the European periphery countries are more sensitive to changes in the cost of capital in the longterm than banks in the core countries. This finding is consistent with the previous estimations for the short-term.

As explained in the previous subsection, we are also interested in analysing the effects of the sovereign debt crisis on the supply of credit. In Panel B of Table 7 we substitute the Crisist time dummy for the 10-year sovereign bonds CDS $\left(C D S_{h t}\right)$ for the period 2008Q1 - 2016Q4. The estimations demonstrate that one-standard-deviation increase in $C D S_{h t}$ reduces the supply of credit by 0.69 percent for the Eurozone banks. In line with previous results, the credit supply for banks in the European periphery countries are more sensitive to the sovereign debt crisis than for banks in the core countries. Accordingly, this result is explained through the 'interbank collateral channel' as the transmission mechanism from the price and credibility of sovereign bonds to the supply of credit. Sovereign debt is used as collateral pledged by banks in the interbank markets in order to obtain funding. For this reason, reductions in the value of 
sovereign debt might restrict the access -or increase the cost- of banks to funding, which are the input to generate new credit (see Lakdawala et al., 2017).

\subsection{The effects of the cost of capital on liquidity creation}

The second question to be addressed in this research is whether increases in the cost of capital leads to reductions in liquidity creation $\left(L C_{i t} / T A_{i t}\right)(\mathrm{H}-3)$. The results are shown in Panel A of Table 8. To this purpose, we also estimate equation (11) using the Arellano-Bond GMM estimator. We find that the effects in the short-term and the long-term are negative and significant in line with the results presented above. The estimates also reject the null hypothesis for the cost of capital $\left(H_{0}: \delta^{\prime}{ }_{2}=\delta^{\prime}{ }_{3}=0\right)$ and for the adjustment parameter $\left(H_{0}: \delta^{\prime}{ }_{1}=0\right.$ and $\delta^{\prime}{ }_{1}$ $=1$ ). We also obtain the expected sign for the effects of the cost of capital on liquidity creation in the short-term meaning that increases in the cost capital reduces banks' capacity to generate liquidity. We find that one-standard-deviation increase in the cost of capital $\left(r_{i t}\right)$ reduces liquidity creation by 0.03 percent for the Eurozone banks. According to the results presented above, the results suggest that the effect is also more pronounced for the banks in the European periphery countries than for those headquartered in the core countries. The results are robust after including control variables. In addition, we also investigate the implication of leverage to absorb the effects of the cost of capital on liquidity creation. The negative and significant coefficient for $L E V_{i t}$ reveals that the greater leverage the lower liquidity creation. In line with our findings on lending, leverage enhances the sensitivity of liquidity creation to changes in the bank cost of capital; banks with higher leverage experience greater reductions in their capacity to generate liquidity due to increases in their cost of capital.

As for the long-term, the estimations suggest that one-standard-deviation increase in the cost of capital reduces liquidity creation by 0.12 standard deviations for the Eurozone banks. In line with previous results, liquidity creation is more sensitive to changes in the cost of capital for 
the European periphery country banks (0.19 standard deviations) than for the core country banks ( 0.10 standard deviations). These results are robust to the inclusion of control variables and interactions, since we obtain similar steady state coefficients and standard errors.

Panel B of Table 8 displays the results for the 10-year sovereign bonds CDS $\left(C D S_{h t}\right)$ for the period 2008Q1 - 2016Q4. The results for the cost of capital in the short-term and in the longterm are consistent with those presented in the above regressions. The results also suggest that the sovereign debt crisis reduced liquidity creation for both groups of banks, being the European periphery country banks more sensitive to changes to risk country than those banks operating in the core countries.

To test the robustness of the liquidity variable measure $\left(L C_{i t} / T A_{i t}\right)$ we create a modified measure of liquidity creation by including the items 'Customer deposits-current' and 'Customer deposits-savings' as semiliquid liabilities, and 'customer deposits-term' and 'Deposits from banks' as Liquid liabilities $\left(L C{ }^{\prime}{ }_{i t} / T A_{i t}\right)$. The results are shown in Table 9. We find that the results obtained with the new definition of liquidity creation $\left(L C{ }^{\prime}{ }_{i t} / T A_{i t}\right)$ are robust to the former measure $\left(L C_{i t} / T A_{i t}\right)$.

\subsection{Granger predictability test: Results}

We are also interested in analysis the predictability between the NPLs ratio $\left(N P L_{i t}\right)$, credit supply $\left(L O A N T A_{i t}\right)$ and liquidity creation $\left(L C_{i t} / T A_{i t}\right)$ with the cost of capital $\left(r_{i t}\right)$. We employ the Granger predictability test with four lags for the NPLs ratio, the lending supply variables, and the cost of capital. The vector of instrumental variables includes the unemployment rate $\left(U N E M P_{h t}\right)$ and GDP growth $\left(G D P_{h t}\right)$ at the country level to control for the influence of the business cycle on credit markets and the evolution of NPLs. Finally, valid inference is ensured since standard errors and test statistics are robust to heterokedasticity and clustered at the country level. 
The results shown in Table 10 suggest that the NPLs ratio $\left(N P L_{i t}\right)$ predict the cost of capital $\left(r_{i t}\right)$, but the cost of capital does not predict the NPLs ratio. Similarly, we also find that the cost of capital predicts credit supply $\left(L O A N T A_{i t}\right)$ and liquidity creation $\left(L C_{i t} / T A_{i t}\right)$, but the $L O A N T A_{i t}$ and $\left(L C_{i t} / T A_{i t}\right)$ do not predict the cost od capital.

\subsection{Robustness test: Testing for 'false positives' and 'false negatives' using a subsample of German banks}

The specifications presented in Table 6 suggest that non-performing loans increase the cost of capital for the Eurozone banks, regardless they operate in the European periphery countries or the core countries. Furthermore, the results presented in Table 7 and Table 8 show that the increased cost of capital exert a negative influence in credit supply and liquidity creation.

To test the robustness of the results, we replicate in Appendix B the estimations presented above for a subsample of German banks. We perform this experiment because Germany is the Eurozone country with a relatively low level of NPLs ratio and cost of capital. Importantly, Germany has been immune from the shocks that have affected the European periphery. Since the estimated coefficients are consistent with those derived for the entire sample, we can draw the conclusion that our results are not spurious. In other words, the results support the 'theoretical' relationship among the variables analysed in this research.

\section{Conclusions}

This article analyses the repercussions of NPLs on the cost of capital -or equity- and utterly, on lending and liquidity supply over time. To this purpose, we create a unique dataset by combining information from Bureau van Dijk's Bankscope and Orbis Bank Focus, market information from Thomson Reuters Datastream, and macroeconomic information from Eurostat. 
The results of this study draw the conclusion that banks holding greater levels of NPLs are claimed for increasing profitability by equity investors in the short-term and the long-term. Investors perceive these banks as riskier than their counterparts or other assets, claiming greater returns on the equity holdings of these banks and hence inducing an increase in their cost of capital.

As a result, these banks will have a restricted access to equity, thus reducing their lending and liquidity provision. To the best of our knowledge, this is one of the first papers to disentangle this transmission channel. Furthermore, we find that the transmission channel from NPLs to bank cost of capital, credit and liquidity provision is economically more significant for banks operating in the so-called European periphery countries than those based in the core countries.

Finally, the Granger predictability test confirms the transmission channel: the NPLs ratio is a determinant of the cost of capital, but not otherwise. Similarly, the cost of capital predicts credit and liquidity supply, but no predictability is found in the opposite direction. The results are robust after repeating the experiment for a subsample of German banks. 
Table 1: Variable definition

\begin{tabular}{|c|c|c|c|}
\hline Variable & Acronym & Definition & Source \\
\hline \multicolumn{4}{|l|}{ Bank variables } \\
\hline $\begin{array}{l}\text { Banks’ Beta- } \\
\text { CAPM }\end{array}$ & $\beta_{i t}$ & $\begin{array}{l}\text { This variable measures the sensitivity of expected } \\
\text { excess bank's capital assets returns to the } \\
\text { expected excess market returns. This coefficient } \\
\text { represents bank's risk taking. }\end{array}$ & $\begin{array}{l}\text { Authors' calculation } \\
\text { based on Thomson } \\
\text { Reuters Datastream. }\end{array}$ \\
\hline $\begin{array}{l}\text { Non-performing } \\
\text { loans ratio }\end{array}$ & $N P L_{i t}$ & $\begin{array}{l}\text { This variable is measured as the ratio impaired } \\
\text { loans over total loans. }\end{array}$ & Bankscope \\
\hline Return on equity & $R O E_{i t}$ & $\begin{array}{l}\text { This variable controls for bank's performance. } \\
\text { This ratio is measured as operating profits (loss) } \\
\text { over total equity. }\end{array}$ & Bankscope \\
\hline Cost of capital & $r_{i t}$ & $\begin{array}{l}\text { This variable measures investors' required return } \\
\text { on bank equity. This indicator is computed as } \\
r_{i t}=E\left[R_{i t}\right]=R_{t}^{f}+\beta_{i t}\left(E\left[R_{t}^{m}\right]-R_{t}^{f}\right)=R_{t}^{f}+ \\
\beta_{i t} E R P_{t} .\end{array}$ & $\begin{array}{l}\text { Author's calculation } \\
\text { based on Bankscope and } \\
\text { Thomson Reuters } \\
\text { Datastream. }\end{array}$ \\
\hline Profitability gap & $r_{i t}-R O E_{i t}$ & $\begin{array}{l}\text { This variable measures the difference between } \\
\text { the investors' required return and the profitability } \\
\text { that the bank is able to generate. }\end{array}$ & $\begin{array}{l}\text { Author's calculation } \\
\text { based on Bankscope and } \\
\text { Thomson Reuters } \\
\text { Datastream. }\end{array}$ \\
\hline Bank's size & Size $_{i t}$ & $\begin{array}{l}\text { Natural logarithm of one-period lagged total } \\
\text { assets. }\end{array}$ & Bankscope \\
\hline Customer loans & $L_{O A N T A}$ & $\begin{array}{l}\text { This ratio measures the bank's business volume. } \\
\text { This variable is measured as customer loans over } \\
\text { total assets. }\end{array}$ & Bankscope \\
\hline $\begin{array}{l}\text { Liquidity } \\
\text { creation }\end{array}$ & $L C_{i t} / T A_{i t}$ & $\begin{array}{l}L C_{i t}=0.5 \times \text { (illiquid assets }+ \text { liquid liabilities }- \\
\text { liquid assets }- \text { illiquid liabilities }- \text { equity })\end{array}$ & Bankscope \\
\hline Leverage & $L E V_{i t}$ & $\begin{array}{l}\text { This ratio controls for bank's solvency. This } \\
\text { variable is constructed as the ratio bank total } \\
\text { assets over total equity. }\end{array}$ & Bankscope \\
\hline $\begin{array}{l}\text { Degree of } \\
\text { competition }\end{array}$ & Lerner $_{i t}$ & $\begin{array}{l}\text { This index is defined as the difference between } \\
\text { the price and bank's marginal costs over the } \\
\text { price. This variable measures the capacity of the } \\
\text { bank to set a price above the marginal costs. }\end{array}$ & Bankscope \\
\hline Income structure & $I N C_{i t}$ & $\begin{array}{l}\text { This ratio is measured as non-interest income } \\
\text { over total net income. This variable controls for } \\
\text { business diversification. }\end{array}$ & Bankscope \\
\hline Efficiency & $E F F_{i t}$ & $\begin{array}{l}\text { This ratio is measured as operating costs over } \\
\text { gross income. }\end{array}$ & Bankscope \\
\hline \multicolumn{4}{|c|}{ Macroeconomic variables } \\
\hline Crisis dummy & Crisis $_{t}$ & $\begin{array}{l}\text { Dummy variable which takes the value one if } \\
\text { from } 2007 \mathrm{Q} 3 \text { onwards, and zero otherwise. }\end{array}$ & Eurostat \\
\hline $\begin{array}{l}\text { Sovereign credit } \\
\text { risk }\end{array}$ & $C D S_{h t}$ & $\begin{array}{l}\text { This variable is the } 10 \text {-years maturity sovereign } \\
\text { Credit Default Swaps (CDS) at the country level } \\
\text { (h). }\end{array}$ & $\begin{array}{l}\text { Thomson } \\
\text { Datastream }\end{array}$ \\
\hline GDP growth & $G D P_{h t}$ & $\begin{array}{l}\text { This variable is measured as the variation rate of } \\
\text { GDP at the country level }(h) \text {. }\end{array}$ & Eurostat \\
\hline $\begin{array}{l}\text { Unemployment } \\
\text { rate }\end{array}$ & $U N E M P_{h t}$ & $\begin{array}{l}\text { This variable is measured as the unemployment } \\
\text { rate at the country level }(h) \text {. }\end{array}$ & Eurostat \\
\hline
\end{tabular}

Notes: $i, h$, and $t$ subscripts refer to bank, country and time, respectively. 
Table 2. Descriptive statistics

This table reports the distribution of the variables used in this research between 2002Q1 and 2016Q4.Values for CDS are available from 2008Q1 to 2016Q4. Panel A shows the descriptive statistics of the sample. Panel B displays mean values and standard errors for the same variables but referred to the years before (2002Q1 2007Q2) and after (2007Q3 - 2016Q4) the crisis. $\beta_{i t}$ is measured as the covariance between the return of the stock $i$ and the return of the market portfolio over the variance of the market portfolio return. $\mathrm{ERP}_{\mathrm{t}}$ is calculated as the historical mean of the realized EURO STOXX returns in excess of the contemporaneous 10-year bund yield over the past 60 months (five years) of observations, beginning in January 1990. The cost of capital $\left(r_{i t}\right)$ is investors' required return on bank equity computed as the return of the risk-free asset plus $\beta_{i t}$ times equity risk premium $\left(E R P_{t}\right)$. The Return on Equity $\left(R O E_{i t}\right)$ is measured as operating profits (losses) over total equity. The variable $r_{i t}$ $R O E_{i t}$ represents the profitability gap. $N P L_{i t}$ is measured as the ration impaired loans to total loans. Size $e_{i t}$ is the natural logarithm of one-period lagged total assets $\left(T A_{i t}\right) . L E V_{i t}$ is measured as total assets over total equity. Lerner $_{i t}$ is computed as the price minus marginal costs over price. $I N C_{i t}$ is the non-interest income over total net income ratio. $E F F_{i t}$ is calculated as the operating costs over gross income ratio. $C D S_{h t}$ is the 10 -years maturity sovereign Credit Default Swaps (CDS) at the country level (h). GDP it is measured as the variation rate of GDP at the country level $(h) . U N E M P_{h t}$ is measured as the unemployment rate at the country level $(h)$. The parametric tests estimate the differences in mean values under the null $\mathrm{H}_{0}$ : Crisis $\mathrm{C}_{t}(0)-$ Crisis $_{t}(1)=0$, being Crisis $t_{t}=1$ if $t \geq$ 2007Q3, and zero, otherwise. The sample includes commercial banks, savings banks, and credit unions existing in the Euro area countries.

PANEL A: Description of the sample

\begin{tabular}{|c|c|c|c|c|c|c|c|c|}
\hline & $\mathbf{N}$ & Mean & SD & Min. & Pc. 25 & Median & Pc. 75 & Max. \\
\hline \multicolumn{9}{|c|}{ Bank variables } \\
\hline$\beta_{i t}$ & 2,400 & 1.7658 & 0.5490 & 1.0312 & 1.2797 & 1.6806 & 2.1804 & 2.8976 \\
\hline$E R P_{t}$ & 2,400 & 0.0710 & 0.0303 & 0.0333 & 0.0409 & 0.0647 & 0.1064 & 0.1239 \\
\hline$r_{i t}$ & 2,400 & 0.1609 & 0.0657 & 0.0802 & 0.1067 & 0.1467 & 0.2010 & 0.3078 \\
\hline$r_{i t}-R O E_{i t}$ & 2,400 & 0.1236 & 0.1663 & 0.0001 & 0.0075 & 0.1047 & 0.1996 & 0.5528 \\
\hline$N P L_{i t}$ & 2,400 & 0.0875 & 0.0846 & 0.0063 & 0.0343 & 0.0607 & 0.1136 & 0.4785 \\
\hline Size $_{i t}$ & 2,400 & 24.2487 & 2.1571 & 18.5862 & 22.7461 & 24.0957 & 25.8649 & 28.2834 \\
\hline$R O E_{i t}$ & 2,400 & 0.0588 & 1308 & -0.3235 & 0.0250 & 0.0787 & 0.1268 & 0.2609 \\
\hline LOANTA $_{i t}$ & 2,400 & 0.5964 & 0.2028 & 0.0552 & 0.5340 & 0.6357 & 0.7477 & 0.8781 \\
\hline$L C_{i t} / T A_{i t}$ & 2,400 & 0.3180 & 2765 & -0.4631 & 0.1243 & 0.3299 & 0.5172 & 1.0236 \\
\hline$L C{ }_{i t} / T A_{i t}$ & 2,400 & 0.2132 & 0.1911 & -0.4242 & 0.1024 & 0.2358 & 0.3323 & 0.7347 \\
\hline$L E V_{i t}$ & 2,400 & 16.3633 & 7.8301 & 4.3577 & 11.0884 & 14.8399 & 19.1339 & 46.5409 \\
\hline Lerner $_{i t}$ & 2,400 & 0.1020 & 0333 & 0.0784 & 0.0784 & 0.1020 & 0.1255 & 0.1255 \\
\hline$I N C_{i t}$ & 2,400 & 0.3625 & 0.2257 & 0.0000 & 0.2250 & 0.3084 & 0.4256 & 1.1734 \\
\hline$E F F_{i t}$ & 2,400 & 0.3044 & 0.1364 & 0.1020 & 0.2152 & 0.2700 & 0.3514 & 0.8571 \\
\hline \multicolumn{9}{|c|}{ Macroeconomic variables } \\
\hline Crisis $_{t}$ & 2,400 & 0.6333 & 0.4820 & 0.0000 & 0.0000 & 1.0000 & 1.0000 & 1.0000 \\
\hline$C D S_{i t}$ & 1,251 & 124.7894 & 140.9011 & 10.3333 & 46.0500 & 76.5000 & 145.6400 & 1190.6200 \\
\hline$G D P_{h t}$ & 2,460 & 0.0131 & 0.0271 & -0.0983 & 0.0030 & 0.0136 & 0.0269 & 0.2760 \\
\hline$U N E M P_{h t}$ & 2,400 & 8.9772 & 4.4502 & 3.1333 & 5.7333 & 8.3000 & 10.2333 & 26.2000 \\
\hline
\end{tabular}


PANEL B: Parametric test for comparison of means before (2002Q1 - 2007Q2) and after (2007Q3 - 2016Q4) the crisis $\left(\mathrm{H}_{0}\right.$ : Crisis $t(0)-$ Crisis $\left._{t}(1)=0\right)$. Standard errors in parentheses.

\begin{tabular}{|c|c|c|c|}
\hline & 2002Q1 - 2007Q2 & 2007Q3 - 2016Q4 & $\begin{array}{c}\text { t-test } \\
{[p \text {-value }]}\end{array}$ \\
\hline \multirow[t]{2}{*}{$\beta_{i t}$} & 1.6653 & 1.8182 & -8.3959 \\
\hline & $(0.0138)$ & $(0.0109)$ & {$[0.0000]$} \\
\hline \multirow[t]{2}{*}{$r_{i t}$} & 0.1170 & 0.1837 & -34.6443 \\
\hline & $(0.0009)$ & $(0.0013)$ & {$[0.0000]$} \\
\hline \multirow[t]{2}{*}{$r_{i t}-R O E_{i t}$} & 0.0877 & 0.1924 & -5.3886 \\
\hline & (0.0109) & $(0.0041)$ & {$[0.0000]$} \\
\hline \multirow[t]{2}{*}{$N P L_{i t}$} & 0.0465 & 0.0937 & -5.2897 \\
\hline & $(0.0043)$ & $(0.0034)$ & {$[0.0000]$} \\
\hline \multirow[t]{2}{*}{ Size $_{i t}$} & 24.0591 & 24.2878 & -1.4132 \\
\hline & $(0.1422)$ & $(0.0673)$ & {$[0.0789]$} \\
\hline \multirow[t]{2}{*}{$R O E_{i t}$} & 0.1243 & 0.0465 & 18.1944 \\
\hline & $(0.0029)$ & $(0.0018)$ & {$[0.0000]$} \\
\hline \multirow[t]{2}{*}{$L_{O A N T A}$} & 0.5660 & 0.6026 & -2.4042 \\
\hline & $(0.0116)$ & $(0.0068)$ & [0.0082] \\
\hline \multirow[t]{2}{*}{$L C_{i t} / T A_{i t}$} & 0.2785 & 0.3024 & -2.8234 \\
\hline & $(0.0074)$ & $(0.0036)$ & {$[0.0024]$} \\
\hline \multirow[t]{2}{*}{$L C^{\prime}{ }_{i t} / T A_{i t}$} & 0.2234 & 0.2111 & 2.1478 \\
\hline & $(0.0054)$ & $(0.0023)$ & [0.0159] \\
\hline \multirow[t]{2}{*}{$L E V_{i t}$} & 17.8797 & 16.0513 & 3.1218 \\
\hline & $(0.4686)$ & $(0.2475)$ & {$[0.0009]$} \\
\hline
\end{tabular}


Table 3. Parametric tests for comparison of means for European core and periphery countries, before and after the crisis.

This table breaks the sample down between banks in the European periphery countries (Cyprus, Greece, Ireland, Italy, Latvia, Lithuania, Portugal, Slovakia, Spain) and in the European core countries (Austria, Belgium, Estonia, Finland, France, Germany, Luxembourg, Malta, Slovenia, and The Netherlands). The parametric tests are performed under the null Ho: Core ( 0 ) - Periphery (1) = 0 for the following periods: (i) the whole period (2002Q1 - 2016Q4), (ii) before the crisis (2002Q1 - 2007Q2), and (iii) after the crisis (2007Q3 - 2016Q4). $\beta_{i t}$ is measured as the covariance between the return of the stock $i$ and the return of the market portfolio over the variance of the market portfolio return. The cost of capital $\left(r_{i t}\right)$ is investors' required return on bank equity computed as the return of the risk-free asset plus $\beta_{i t}$ times equity risk premium $\left(E R P_{t}\right)$. The Return on Equity $\left(R O E_{i t}\right)$ is measured as operating profits (losses) over total equity. The variable $r_{i t}-R O E_{i t}$ represents the profitability gap. $N P L_{i t}$ is measured as the ration impaired loans to total loans. $S i z e_{i t}$ is the natural logarithm of one-period lagged total assets (TA $\left.A_{i t}\right)$. $L O A N T A_{i t}$ is the ratio customers' loans to total assets. $L C_{i t} / T A_{i t}$ is measured as $0.5 \times$ (illiquid assets + liquid liabilities - liquid assets - illiquid liabilities - equity) $/ T A_{i t}$. The variable $L C$ ' ${ }_{i t}$ includes the items 'Customer depositscurrent' and 'Customer deposits-savings' as semiliquid liabilities, and 'customer deposits-term' and 'Deposits from banks' as Liquid liabilities. $L E V_{i t}$ is measured as total assets over total equity. $C D S h t$ is the 10-years maturity sovereign Credit Default Swaps (CDS) at the country level $(h)$. The coefficients represent mean values, whereas standard errors are in parentheses. The t-statistics is reported for each test, and the $p$-value is shown in brackets.

\begin{tabular}{|c|c|c|c|c|c|c|c|c|c|}
\hline & \multicolumn{3}{|c|}{ 2002Q1 - 2016Q4 } & \multicolumn{3}{|c|}{$2002 Q 1-2007 Q 2$} & \multicolumn{3}{|c|}{ 2007Q3-2016Q4 } \\
\hline & Core & Periphery & $\begin{array}{c}\text { t-test } \\
{[p \text {-value }]}\end{array}$ & Core & Periphery & $\begin{array}{c}\text { t-test } \\
{[p \text {-value }]}\end{array}$ & Core & Periphery & $\begin{array}{c}\text { t-test } \\
{[p \text {-value }]}\end{array}$ \\
\hline \multirow[t]{2}{*}{$\beta_{i t}$} & 1.6770 & 1.8296 & -8.7096 & 1.6243 & 1.6942 & -2.4850 & 1.7041 & 1.9012 & -8.9922 \\
\hline & $(0.0127)$ & $(0.0117)$ & {$[0.0000]$} & $(0.0217)$ & $(0.0179)$ & {$[0.0065]$} & $(0.0156)$ & $(0.0148)$ & [0.0000] \\
\hline \multirow[t]{2}{*}{$r_{i t}$} & 0.1550 & 0.1650 & -4.7107 & 0.1145 & 0.1187 & -2.2761 & 0.1759 & 0.1894 & -5.1488 \\
\hline & $(0.0015)$ & $(0.0014)$ & {$[0.0000]$} & $(0.0014)$ & $(0.0012)$ & {$[0.0115]$} & $(0.0019)$ & $(0.0017)$ & {$[0.0000]$} \\
\hline \multirow[t]{2}{*}{$r_{i t}-R O E_{i t}$} & 0.1412 & 0.2100 & -8.1650 & 0.0738 & 0.1117 & -1.6861 & 0.1427 & 0.2158 & -8.4328 \\
\hline & $(0.0049)$ & $(0.0053)$ & {$[0.0000]$} & $(0.0107)$ & $(0.0231)$ & {$[0.0963]$} & $(0.0050)$ & $(0.0054)$ & {$[0.0000]$} \\
\hline \multirow[t]{2}{*}{$N P L_{i t}$} & 0.0386 & 0.1018 & -9.0369 & 0.0568 & 0.0444 & 1.0806 & 0.0366 & 0.1114 & -9.9275 \\
\hline & $(0.0018)$ & $(0.0037)$ & {$[0.0000]$} & $(0.0086)$ & $(0.0049)$ & {$[0.2825]$} & $(0.0018)$ & $(0.0041)$ & {$[0.0000]$} \\
\hline \multirow[t]{2}{*}{ Size $_{i t}$} & 23.7881 & 24.4791 & -5.4071 & 23.9616 & 24.0927 & -0.4018 & 23.7618 & 24.5698 & -5.8098 \\
\hline & $(0.1262)$ & $(0.0646)$ & {$[0.0000]$} & $(0.3405)$ & $(0.1516)$ & [0.6882] & $(0.1361)$ & $(0.0711)$ & {$[0.0000]$} \\
\hline \multirow[t]{2}{*}{$R O E_{i t}$} & 0.0761 & 0.0445 & 9.8814 & 0.1120 & 0.1345 & -3.7650 & 0.0693 & 0.0276 & 11.8953 \\
\hline & $(0.0019)$ & $(0.0024)$ & [0.0000] & $(0.0045)$ & $(0.0039)$ & [0.0002] & $(0.0021)$ & $(0.0027)$ & [0.0000] \\
\hline \multirow[t]{2}{*}{$L_{O A N T A_{i t}}$} & 0.4868 & 0.6510 & -14.5876 & 0.4634 & 0.6017 & -5.5477 & 0.4903 & 0.6625 & -13.7765 \\
\hline & $(0.0135)$ & $(0.0042)$ & {$[0.0000]$} & $(0.0314)$ & $(0.0098)$ & {$[0.0000]$} & $(0.0148)$ & $(0.0045)$ & [0.0000] \\
\hline \multirow[t]{2}{*}{$L C_{i t} / T A_{i t}$} & 0.3279 & 0.2663 & 9.6727 & 0.3211 & 0.2219 & 6.7324 & 0.3296 & 0.2744 & 7.8057 \\
\hline & $(0.0042)$ & $(0.0048)$ & {$[0.0000]$} & $(0.0086)$ & $(0.0125)$ & [0.0000] & $(0.0048)$ & $(0.0052)$ & [0.0000] \\
\hline \multirow[t]{2}{*}{$L C^{\prime}{ }_{i t} / T A_{i t}$} & 0.2400 & 0.1843 & 12.9074 & 0.2616 & 0.1727 & 8.2823 & 0.2349 & 0.1865 & 10.2838 \\
\hline & $(0.0029)$ & $(0.0031)$ & [0.0000] & $(0.0067)$ & $(0.0085)$ & {$[0.0000]$} & $(0.0033)$ & $(0.0033)$ & {$[0.0000]$} \\
\hline \multirow[t]{2}{*}{$L E V_{i t}$} & 17.3101 & 15.8899 & 3.0375 & 20.9633 & 16.8130 & 4.0042 & 16.7565 & 15.6731 & 2.0895 \\
\hline & $(0.5207)$ & $(0.2038)$ & {$[0.0012]$} & (1.4619) & $(0.3432)$ & {$[0.0000]$} & $(0.5523)$ & $(0.2377)$ & [0.0185] \\
\hline \multirow[t]{2}{*}{$C D S_{h t}$} & - & - & - & - & - & - & 66.3132 & 154.9519 & -11.7934 \\
\hline & & & & & & & $(2.3452)$ & $(5.9483)$ & {$[0.0000]$} \\
\hline
\end{tabular}


Table 4. Means of the key variables depending on the quartiles of $N P L_{i t}$.

This table displays the summary statistics of the main variables employed in this study by quartiles of non-performing loans ratio $\left(N P L_{i t}\right)$ calculated as impaired loans to total loans for the whole sample. The regression coefficients represent the mean variable, whilst the standard errors are represented in parentheses. All specifications are estimated using OLS. $\beta_{i t}$ is measured as the covariance between the return of the stock $i$ and the return of the market portfolio over the variance of the market portfolio return. The cost of capital $\left(r_{i t}\right)$ is investors' required return on bank equity computed as the return of the risk-free asset plus $\beta_{i t}$ times equity risk premium $\left(E R P_{t}\right)$. The Return on Equity $\left(R O E_{i t}\right)$ is measured as operating profits (losses) over total equity. The variable $r_{i t}-R O E_{i t}$ represents the profitability gap. Size $i t$ is the natural logarithm of one-period lagged total assets $\left(T A_{i t}\right)$. The F-statistics are shown to test the differences in the dependent variables amongst the quartiles of $N P L_{i t}$, and the $p$-value is represented in brackets. Estimates followed by $*, * *, * * *$ are statistically significant at the $10 \%, 5 \%$, and $1 \%$, respectively.

\begin{tabular}{lccccc}
\hline \hline & 1st Quartile & 2nd Quartile & 3rd Quartile & 4th Quartile & $\begin{array}{c}\text { F-test } \\
{[p \text {-value }]}\end{array}$ \\
\hline$\beta_{i t}$ & $1.8142^{* * *}$ & $1.8334^{* * *}$ & $1.9696^{* * * *}$ & $2.2221^{* * *}$ & $5,754.41$ \\
$r_{i t}$ & $(0.0275)$ & $(0.0262)$ & $(0.0242)$ & $(0.0261)$ & {$[0.0000]$} \\
& $0.1528^{* * *}$ & $0.1754^{* * *}$ & $0.2077^{* * *}$ & $0.2113^{* * *}$ & $3,053.36$ \\
$r_{i t}-$ ROE $_{i t}$ & $(0.0036)$ & $(0.0034)$ & $(0.0032)$ & $(0.0034)$ & {$[0.0000]$} \\
& $0.1290^{* * *}$ & $0.1407^{* * *}$ & $0.1904^{* * *}$ & $0.2755^{* * *}$ & 521.95 \\
Size $i t$ & $(0.0092)$ & $(0.0113)$ & $(0.0079)$ & $(0.0081)$ & {$[0.0000]$} \\
& $24.540^{* * *}$ & $25.512^{* * *}$ & $25.070^{* * *}$ & $24.786^{* * *}$ & $38,949.65$ \\
$R O E_{i t}$ & $(0.127)$ & $(0.127)$ & $(0.127)$ & $(0.127)$ & {$[0.0000]$} \\
& $0.1132^{* * *}$ & $0.0912^{* * *}$ & $0.0560^{* * *}$ & $-0.0387^{* * *}$ & 456.61 \\
& $(0.0037)$ & $(0.0037)$ & $(0.0038)$ & $(0.0038)$ & {$[0.0000]$} \\
\hline
\end{tabular}


Table 5: Unit root and cointegration analysis with structural break

This table presents the results of the tests for unit root and cointegration. Panel A displays the Augmented Dickey-Fuller test for the key variables employed in this study. The coefficients represent the impact on the one-period-lagged coefficient of the dependent variable, whilst the standard errors are represented in parentheses. Panel B shows the results of the Johansen-Fisher's panel cointegration test for the endogenous variables of this study. Endogenous variables include the cost of capital $\left(r_{i t}\right)$ defined by investors' required return on bank equity computed as the return of the risk-free asset plus $\beta_{i t}$ times equity risk premium $\left(E R P_{t}\right)$; NPLs ratio $\left(N P L_{i t}\right)$ measured as the ratio impaired loans over total loans; credit supply $\left(L O A N T A_{i t}\right)$ calculated as the ratio customers' loans to total assets $\left(T A_{i t}\right)$; liquidity creation $\left(L C_{i t} / T A_{i t}\right)$ computed as $0.5 \times$ (illiquid assets + liquid liabilities - liquid assets - illiquid liabilities equity) $/ T A_{i t}$; and the modified liquidity creation $\left(L C{ }^{\prime}{ }_{i t} / T A_{i t}\right)$ that includes the items 'Customer deposits-current' and 'Customer deposits-savings' as semiliquid liabilities, and 'customer depositsterm' and 'Deposits from banks' as Liquid liabilities. Trace (statistical $t$ ) is reported for the years before (2002Q1 - 2007Q2) and after (2007Q3 - 2016Q4) the crisis. Estimates followed by *,**,*** represent the rejection of the null hypothesis of unit roots at the 10,5 , and $1 \%$, respectively; whilst estimates followed by,,++++++ mean that cointegration exists at the 10,5 , and $1 \%$ respectively.

PANEl A: Augmented Dickey-Fuller test with four lags

\begin{tabular}{|c|c|c|c|c|c|c|}
\hline & \multicolumn{2}{|c|}{ Model A } & \multicolumn{2}{|c|}{ Model B } & \multicolumn{2}{|c|}{ Model C } \\
\hline & Coefficient $\left(\theta_{1}\right)$ & t-stats & Coefficient $\left(\theta_{1}\right)$ & t-stats & Coefficient $\left(\theta_{1}\right)$ & t-stats \\
\hline$r_{i t}$ & $\begin{array}{c}-0.4807^{* * *} \\
(0.0266)\end{array}$ & -18.71 & $\begin{array}{c}-0.4584^{* * *} \\
(0.0214)\end{array}$ & -21.42 & $\begin{array}{c}-0.4556^{* * *} \\
(0.0286)\end{array}$ & -15.93 \\
\hline$N P L_{i t}$ & $\begin{array}{c}-0.6033^{* * * *} \\
(0.2655)\end{array}$ & -2.27 & $\begin{array}{l}-0.6034^{* *} \\
(0.2655)\end{array}$ & -2.27 & $\begin{array}{l}-0.6034^{* *} \\
(0.2665)\end{array}$ & -2.27 \\
\hline $\operatorname{LOANTA}_{i t}$ & $\begin{array}{c}-0.8937^{* * * *} \\
(0.0680)\end{array}$ & -13.13 & $\begin{array}{c}-0.8433^{* * * *} \\
(0.0498)\end{array}$ & -16.91 & $\begin{array}{c}-0.6922^{* * * *} \\
(0.1672)\end{array}$ & -4.14 \\
\hline$L C_{i t} / T A_{i t}$ & $\begin{array}{c}-0.8099^{* * * *} \\
(0.1888)\end{array}$ & -4.29 & $\begin{array}{l}-0.7064^{* *} \\
(0.1979)\end{array}$ & -3.57 & $\begin{array}{c}-0.7197^{\text {**** }} \\
(0.0737)\end{array}$ & -9.76 \\
\hline$L C^{\prime}{ }_{i t} / T A_{i t}$ & $\begin{array}{c}-0.7875^{* * *} \\
(0.1090)\end{array}$ & -7.22 & $\begin{array}{c}-0.6467^{* *} \\
(0.2567)\end{array}$ & -2.52 & $\begin{array}{c}-0.7938^{* * * *} \\
(0.0759)\end{array}$ & -10.45 \\
\hline
\end{tabular}

PANEL B: Johansen-Fisher's panel cointegration test. Endogenous variable: $r_{i t}$

\begin{tabular}{lcccc}
\hline \hline \multicolumn{2}{c}{$\mathrm{H}_{0}$ : Range $=\mathrm{r}$} & $\mathbf{2 0 0 2 Q 1 - 2 0 0 7 Q 2}$ & & $\mathbf{2 0 0 7 Q 3 - 2 0 1 6 Q 4}$ \\
${$\cline { 1 - 2 }$} }$ & $\mathrm{r}=0$ & $106.0438^{+++}$ & & $338.4015^{+++}$ \\
& $\mathrm{r} \leq 1$ & $42.1169^{+++}$ & & $100.0807^{+++}$ \\
LOANTA $_{i t}$ & $\mathrm{r}=0$ & $184.7151^{+++}$ & & $768.1435^{+++}$ \\
& $\mathrm{r} \leq 1$ & $65.0611^{+++}$ & & $163.8656^{+++}$ \\
$L C_{i t} / T A_{i t}$ & $\mathrm{r}=0$ & $116.3871^{+++}$ & & $497.4280^{+++}$ \\
& $\mathrm{r} \leq 1$ & $56.3515^{+++}$ & & $92.7950^{+++}$ \\
$L C^{+}{ }_{i t} / T A_{i t}$ & $\mathrm{r}=0$ & $124.6141^{+++}$ & & $488.7806^{+++}$ \\
& $\mathrm{r} \leq 1$ & $52.5215^{+++}$ & & $90.1121^{+++}$ \\
\hline
\end{tabular}


Table 6. The effects of non-performing loans on bank's cost of capital $\left(r_{i t}\right)$.

This table provides the regression results of the effects of the non-performing loans ratio $\left(N P L_{i t}\right)$, measured as the ration impaired loans to total loans, on bank's cost of capital. Quarterly observations for Eurozone listed banks are applied for all the specifications. Panel A includes the regression analysis the whole sample. Panel B includes the regression results for the post-crisis period. The dependent variable is the cost of capital $\left(r_{i t}\right)$ defined by investors' required return on bank equity computed as the return of the risk-free asset plus $\beta_{i t}$ times equity risk premium $\left(E R P_{t}\right)$. Size $e_{i t}$ is the natural logarithm of one-period lagged total assets $\left(T A_{i t}\right) . L E V_{i t}$ is measured as total

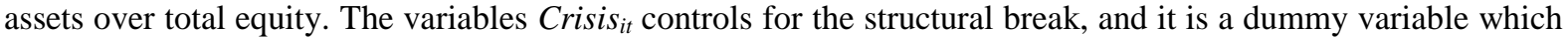
takes the value one after the beginning of the crisis $(t \geq 2007 \mathrm{Q} 3)$, and zero, otherwise. $C D S_{h t}$ is the 10 -years maturity sovereign Credit Default Swaps (CDS) at the country level $(h)$. Values for CDS are available from 2008Q1 to 2016Q4. All the specifications are estimated using the Arellano and Bond's (1991) GMM. The set of instruments includes $t-2, t-3$, and $t$-4 lagged variables. Economic growth $\left(G D P_{h t}\right)$ and unemployment rate $\left(U N E M P_{h t}\right)$ are included as exogenous variables. Instruments validity is tested using a Sargan test of overidentifying restrictions and serial correlation tests ( $p$-values). The steady state denotes the long-term effect between the dependent variable and the NPL ratio. Columns (1) and (4) display the regression values for all the countries, columns (2) and (5) for the periphery countries, and columns (3) and (6) for the core countries. Standard errors are in parenthesis and clustered at the bank level. Estimated followed by *,**, *** are statistically significant at the 10,5 and $1 \%$ level, respectively.

\begin{tabular}{|c|c|c|c|c|c|c|}
\hline & \multicolumn{3}{|c|}{$\begin{array}{l}\text { PANEL A: The whole period } \\
\text { (2002Q1-2016Q4) }\end{array}$} & \multicolumn{3}{|c|}{$\begin{array}{l}\text { PANEL B: The period after the crisis } \\
(2008 \mathrm{Q} 1-2016 \mathrm{Q})\end{array}$} \\
\hline & Eurozone & $\begin{array}{l}\text { Periphery } \\
\text { Countries }\end{array}$ & $\begin{array}{c}\text { Core } \\
\text { Countries }\end{array}$ & Eurozone & $\begin{array}{l}\text { Periphery } \\
\text { Countries }\end{array}$ & $\begin{array}{c}\text { Core } \\
\text { Countries }\end{array}$ \\
\hline & (1) & $(2)$ & (3) & (4) & $(5)$ & (6) \\
\hline$r_{i t-1}$ & $\begin{array}{l}0.482^{* * *} \\
(0.011)\end{array}$ & $\begin{array}{l}0.542^{* * *} \\
(0.016)\end{array}$ & $\begin{array}{l}0.431^{* * *} \\
(0.013)\end{array}$ & $\begin{array}{l}0.515^{* * *} \\
(0.022)\end{array}$ & $\begin{array}{l}0.534^{* * *} \\
(0.031)\end{array}$ & $\begin{array}{l}0.447^{* * *} \\
(0.023)\end{array}$ \\
\hline$N P L_{i t}$ & $\begin{array}{l}0.046^{\text {*** }} \\
(0.013)\end{array}$ & $\begin{array}{l}0.053^{\text {*** }} \\
(0.012)\end{array}$ & $\begin{array}{l}0.034^{\text {*** }} \\
(0.012)\end{array}$ & $\begin{array}{l}0.065^{* * *} \\
(0.021)\end{array}$ & $\begin{array}{l}0.074^{* * *} \\
(0.023)\end{array}$ & $\begin{array}{l}0.054^{* * *} \\
(0.022)\end{array}$ \\
\hline$N P L_{i t-1}$ & $\begin{array}{c}0.032^{* * *} \\
(0.015)\end{array}$ & $\begin{array}{l}0.045^{\text {*** }} \\
(0.018)\end{array}$ & $\begin{array}{l}0.025^{\text {*** }} \\
(0.012)\end{array}$ & $\begin{array}{c}0.057^{* * *} \\
(0.015)\end{array}$ & $\begin{array}{c}0.073^{* * *} \\
(0.026)\end{array}$ & $\begin{array}{l}0.052^{* * * *} \\
(0.012)\end{array}$ \\
\hline$L E V_{i t-1}$ & $\begin{array}{l}0.143^{\text {*** }} \\
(0.030)\end{array}$ & $\begin{array}{l}0.153^{* * *} \\
(0.032)\end{array}$ & $\begin{array}{l}0.136^{\text {**** }} \\
(0.030)\end{array}$ & $\begin{array}{l}0.173^{* * *} \\
(0.035)\end{array}$ & $\begin{array}{l}0.179^{* * * *} \\
(0.036)\end{array}$ & $\begin{array}{l}0.162^{\text {**** }} \\
(0.033)\end{array}$ \\
\hline Crisis $_{t}$ & $\begin{array}{c}0.011^{\text {*** }} \\
(0.002)\end{array}$ & $\begin{array}{l}0.016^{\text {*** }} \\
(0.006)\end{array}$ & $\begin{array}{l}0.008^{* * *} \\
(0.002)\end{array}$ & & & \\
\hline$C D S_{h t-1}$ & & & & $\begin{array}{c}0.001^{* * *} \\
(0.000)\end{array}$ & $\begin{array}{c}0.002^{* * *} \\
(0.000)\end{array}$ & $\begin{array}{l}0.001^{* * *} \\
(0.000)\end{array}$ \\
\hline Intercept & $\begin{array}{l}0.018^{* * *} \\
(0.004)\end{array}$ & $\begin{array}{l}0.021^{* * *} \\
(0.007)\end{array}$ & $\begin{array}{l}0.015^{* * *} \\
(0.003)\end{array}$ & $\begin{array}{l}0.017^{* * *} \\
(0.005)\end{array}$ & $\begin{array}{l}0.021^{* * *} \\
(0.006)\end{array}$ & $\begin{array}{l}0.014^{* * *} \\
(0.005)\end{array}$ \\
\hline$X_{i t-1}$ & Yes & Yes & Yes & Yes & Yes & Yes \\
\hline Bank FE & Yes & Yes & Yes & Yes & Yes & Yes \\
\hline Time FE & Yes & Yes & Yes & Yes & Yes & Yes \\
\hline $\begin{array}{l}\text { Steady } \\
\text { state }\end{array}$ & $\begin{array}{c}0.151^{* * *} \\
(0.046)\end{array}$ & $\begin{array}{c}0.214^{* * *} \\
(0.055)\end{array}$ & $\begin{array}{c}0.104^{* * * *} \\
(0.042)\end{array}$ & $\begin{array}{c}0.252^{* * *} \\
(0.064)\end{array}$ & $\begin{array}{c}0.315^{* * *} \\
(0.069)\end{array}$ & $\begin{array}{c}0.192^{* * *} \\
(0.058)\end{array}$ \\
\hline$N$ & 1,134 & 682 & 452 & 451 & 279 & 172 \\
\hline $\begin{array}{l}\text { Sargan } \\
\text { test }\end{array}$ & 0.557 & 0.412 & 0.520 & 0.627 & 0.777 & 0.699 \\
\hline$A R(2)$ & 0.446 & 0.323 & 0.404 & 0.508 & 0.484 & 0.402 \\
\hline$A R(3)$ & 0.379 & 0.267 & 0.335 & 0.289 & 0.330 & 0.375 \\
\hline
\end{tabular}


Table 7. The effects of the cost of capital $\left(r_{i t}\right)$ on the supply of credit $\left(L O A N T A_{i t}\right)$

This table provides the regression results of the effects of the cost of capital $\left(r_{i t}\right)$, defined by investors' required return on bank equity computed as the return of the risk-free asset plus $\beta_{i t}$ times equity risk premium $\left(E R P_{t}\right)$, on credit supply. Quarterly observations for Eurozone listed banks are applied for all the specifications. The dependent variable is the ratio loans to customers to total assets $\left(L O A N T A_{i t}\right)$. Panel A includes the regression analysis the whole sample. Panel B includes the regression results for the post-crisis period. $L E V_{i t}$ is measured as

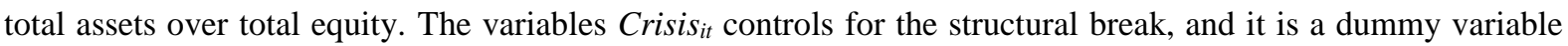
which takes the value one after the beginning of the crisis $(t \geq 2007 \mathrm{Q} 3)$, and zero, otherwise. $C D S_{h t}$ is the 10-years maturity sovereign Credit Default Swaps (CDS) at the country level $(h)$. Values for CDS are available from 2008Q1 to 2016Q4. All the specifications are estimated using the Arellano and Bond's (1991) GMM. The set of instruments include $t-2, t-3$, and $t-4$ lagged variables. Economic growth $\left(G D P_{h t}\right)$ and unemployment rate $\left(U N E M P_{h t}\right)$ are included as exogenous variables. Instruments validity is tested using a Sargan test of overidentifying restrictions and serial correlation tests ( $p$-values). The steady state denotes the long-term effect between the cost of capital and $L O A N T A_{i t}$. All the variables are defined in Table 1. Columns (1) and (4) display the regression values for the whole sample, columns (2) and (5) for the periphery countries, and columns (3) and (6) for the core countries. Standard errors are in parenthesis and clustered at the bank level. Estimated followed by *, $* *, * * *$ are statistically significant at the 10,5 and $1 \%$ level, respectively.

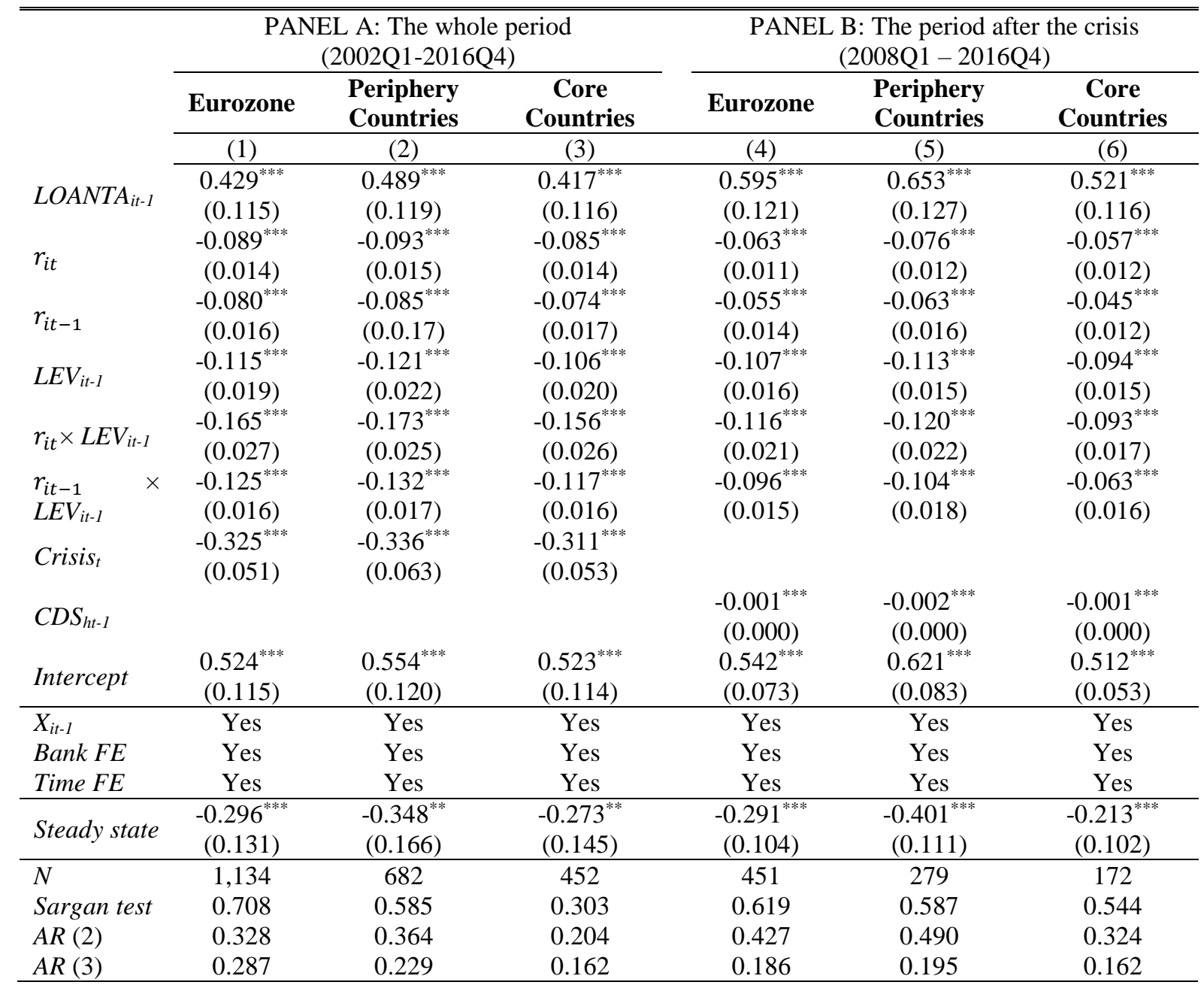


Table 8 . The effects of the cost of capital $\left(r_{i t}\right)$ on liquidity creation $\left(L C_{i} / T A_{i t}\right)$

This table provides the regression results of the effects of the cost of capital $\left(r_{i t}\right)$, defined by investors' required return on bank equity computed as the return of the risk-free asset plus $\beta_{i t}$ times equity risk premium $\left(E R P_{t}\right)$, on liquidity creation. Quarterly observations for Eurozone listed banks are applied for all the specifications. The dependent variable is the ratio liquidity creation to total assets $\left(L C / T A_{i t}\right)$ computed as $0.5 \times$ (illiquid assets + liquid liabilities - liquid assets - illiquid liabilities - equity) over total assets $\left(T A_{i t}\right)$. Panel $\mathrm{A}$ includes the regression analysis the whole sample. Panel $\mathrm{B}$ includes the regression results for the post-crisis period. $L E V_{i t}$ is measured as

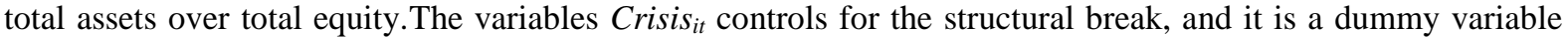
which takes the value one after the beginning of the crisis $(t \geq 2007 \mathrm{Q} 3)$, and zero, otherwise. $C D S_{h t}$ is the 10-years maturity sovereign Credit Default Swaps (CDS) at the country level $(h)$. Values for CDS are available from 2008Q1 to 2016Q4. All the specifications are estimated using the Arellano and Bond's (1991) GMM. The set of instruments include $t-2, t-3$, and $t-4$ lagged variables. Economic growth $\left(G D P_{h t}\right)$ and unemployment rate $\left(U N E M P_{h t}\right)$ are included as exogenous variables. Instruments validity is tested using a Sargan test of overidentifying restrictions and serial correlation tests ( $p$-values). The steady state denotes the long-term effect between the cost of capital and $L C / T A_{i t}$. All the variables are defined in Table 1. Columns (1) and (4) display the regression values for the whole sample, columns (2) and (5) for the periphery countries, and columns (3) and (6) for the core countries. Standard errors are in parenthesis and clustered at the bank level. Estimated followed by *, $* *, * * *$ are statistically significant at the 10,5 and $1 \%$ level, respectively.

\begin{tabular}{|c|c|c|c|c|c|c|}
\hline & \multicolumn{3}{|c|}{$\begin{array}{l}\text { PANEL A: The whole period } \\
\text { (2002Q1-2016Q4) }\end{array}$} & \multicolumn{3}{|c|}{$\begin{array}{l}\text { PANEL B: The period after the crisis } \\
(2008 \mathrm{Q} 1-2016 \mathrm{Q} 4)\end{array}$} \\
\hline & Eurozone & $\begin{array}{l}\text { Periphery } \\
\text { Countries }\end{array}$ & $\begin{array}{c}\text { Core } \\
\text { Countries } \\
\end{array}$ & Eurozone & $\begin{array}{l}\text { Periphery } \\
\text { Countries } \\
\end{array}$ & $\begin{array}{c}\text { Core } \\
\text { Countries } \\
\end{array}$ \\
\hline & (1) & $(2)$ & (3) & (4) & (5) & (6) \\
\hline$(L C / T A)_{\mathrm{it}-}$ & $0.512^{* * *}$ & $0.643^{* * *}$ & $0.442^{* * *}$ & $0.561^{* * *}$ & $0.681^{* * *}$ & $0.432^{* * *}$ \\
\hline 1 & $(0.124)$ & $(0.127)$ & $(0.116)$ & $(0.173)$ & $(0.183)$ & $(0.162)$ \\
\hline$r_{i t}$ & $\begin{array}{c}-0.134^{* * *} \\
(0.023)\end{array}$ & $\begin{array}{c}-0.163^{* * *} \\
(0.032)\end{array}$ & $\begin{array}{c}-0.118^{* * *} \\
(0.023)\end{array}$ & $\begin{array}{c}-0.127^{* * * *} \\
(0.023)\end{array}$ & $\begin{array}{c}-0.153^{* * *} \\
(0.022)\end{array}$ & $\begin{array}{c}-0.103^{* * *} \\
(0.021)\end{array}$ \\
\hline$r_{i t-1}$ & $\begin{array}{c}-0.119^{* * * *} \\
(0.034)\end{array}$ & $\begin{array}{l}-0.125^{* * *} \\
(0.037)\end{array}$ & $\begin{array}{l}-0.106^{* * *} \\
(0.035)\end{array}$ & $\begin{array}{l}-0.084^{* * *} \\
(0.023)\end{array}$ & $\begin{array}{l}-0.119^{* * *} \\
(0.027)\end{array}$ & $\begin{array}{l}-0.084^{* *} \\
(0.027)\end{array}$ \\
\hline$L E V_{i t-1}$ & $\begin{array}{c}-0.074^{* * * *} \\
(0.022)\end{array}$ & $\begin{array}{c}-0.081^{* * * *} \\
(0.024)\end{array}$ & $\begin{array}{c}-0.064^{* * * *} \\
(0.021)\end{array}$ & $\begin{array}{c}-0.073^{* * * *} \\
(0.021)\end{array}$ & $\begin{array}{c}-0.085^{* * *} \\
(0.023)\end{array}$ & $\begin{array}{c}-0.062^{* * * *} \\
(0.021)\end{array}$ \\
\hline$r_{i t} \times L E V_{i t-}$ & $\begin{array}{l}-0.214^{* * *} \\
(0.061)\end{array}$ & $\begin{array}{l}-0.283^{* * *} \\
(0.064)\end{array}$ & $\begin{array}{l}-0.181^{* * *} \\
(0.058)\end{array}$ & $\begin{array}{l}-0.225^{* * *} \\
(0.042)\end{array}$ & $\begin{array}{l}-0.284^{* * * *} \\
(0.046)\end{array}$ & $\begin{array}{l}-0.195^{* * *} \\
(0.043)\end{array}$ \\
\hline $\begin{array}{l}r_{i t-1} \quad \times \\
L E V_{i t-1}\end{array}$ & $\begin{array}{l}-0.123^{* * *} \\
(0.053)\end{array}$ & $\begin{array}{c}-0.142^{* * *} \\
(0.055)\end{array}$ & $\begin{array}{l}-0.114^{* * *} \\
(0.043)\end{array}$ & $\begin{array}{l}-0.143^{* * *} \\
(0.021)\end{array}$ & $\begin{array}{c}-0.164^{* * *} \\
(0.027)\end{array}$ & $\begin{array}{c}-0.126^{* * *} \\
(0.021)\end{array}$ \\
\hline Crisist $_{t}$ & $\begin{array}{c}-0.037^{* * *} \\
(0.006)\end{array}$ & $\begin{array}{c}-0.046^{* * *} \\
(0.009)\end{array}$ & $\begin{array}{c}-0.032^{* * *} \\
(0.005)\end{array}$ & & & \\
\hline$C D S_{h t-1}$ & & & & $\begin{array}{c}-0.001^{* * *} \\
(0.000)\end{array}$ & $\begin{array}{c}-0.002^{* * *} \\
(0.000)\end{array}$ & $\begin{array}{c}-0.001^{* * *} \\
(0.000)\end{array}$ \\
\hline Intercept & $\begin{array}{c}0.253^{* * *} \\
(0.061)\end{array}$ & $\begin{array}{c}0.325^{\text {*** }} \\
(0.068)\end{array}$ & $\begin{array}{c}0.231^{* * *} \\
(0.061)\end{array}$ & $\begin{array}{l}0.252^{* * *} \\
(0.043)\end{array}$ & $\begin{array}{l}0.221^{* * *} \\
(0.048)\end{array}$ & $\begin{array}{l}0.269^{* * *} \\
(0.042)\end{array}$ \\
\hline$X_{i t-1}$ & Yes & Yes & Yes & Yes & Yes & Yes \\
\hline Bank FE & Yes & Yes & Yes & Yes & Yes & Yes \\
\hline Time FE & Yes & Yes & Yes & Yes & Yes & Yes \\
\hline $\begin{array}{l}\text { Steady } \\
\text { state }\end{array}$ & $\begin{array}{c}-0.518^{* * *} \\
(0.248)\end{array}$ & $\begin{array}{c}-0.807^{* * *} \\
(0.365)\end{array}$ & $\begin{array}{c}-0.401^{\text {**** }} \\
(0.243)\end{array}$ & $\begin{array}{c}-0.481^{* * *} \\
(0.164)\end{array}$ & $\begin{array}{c}-0.853^{* * *} \\
(0.238)\end{array}$ & $\begin{array}{c}-0.329^{* * *} \\
(0.129)\end{array}$ \\
\hline$N$ & 1,134 & 682 & 452 & 451 & 279 & 172 \\
\hline $\begin{array}{l}\text { Sargan } \\
\text { test }\end{array}$ & 0.422 & 0.452 & 0.509 & 0.676 & 0.565 & 0.508 \\
\hline$A R(2)$ & 0.266 & 0.379 & 0.361 & 0.361 & 0.404 & 0.340 \\
\hline$A R(3)$ & 0.232 & 0.280 & 0.285 & 0.231 & 0.269 & 0.284 \\
\hline
\end{tabular}


Table 9. The effects of the cost of capital $\left(r_{i t}\right)$ on 'modified' liquidity creation $\left(L C^{\prime}{ }_{i} / T A_{i t}\right)$

This table provides the regression results of the effects of the cost of capital $\left(r_{i t}\right)$, defined by investors' required return on bank equity computed as the return of the risk-free asset plus $\beta_{i t}$ times equity risk premium $\left(E R P_{t}\right)$, on liquidity creation. Quarterly observations for Eurozone listed banks are applied for all the specifications. The dependent variable is the 'modified' ratio liquidity creation to total assets $\left(L C\right.$ ' $\left./ T A_{i t}\right)$. that includes the items 'Customer deposits-current' and 'Customer deposits-savings' as semiliquid liabilities, and 'customer depositsterm' and 'Deposits from banks' as Liquid liabilities. Panel A includes the regression analysis the whole sample. Panel B includes the regression results for the post-crisis period. $L E V_{i t}$ is measured as total assets over total equity. The variables Crisis $_{i t}$ controls for the structural break, and it is a dummy variable which takes the value one after the beginning of the crisis $(t \geq 2007 \mathrm{Q} 3)$, and zero, otherwise. $C D S_{h t}$ is the 10-years maturity sovereign Credit Default Swaps (CDS) at the country level $(h)$. Values for CDS are available from 2008Q1 to 2016Q4. All the specifications are estimated using the Arellano and Bond's (1991) GMM. The set of instruments include $t-2, t-3$, and $t-4$ lagged variables. Economic growth $\left(G D P_{h t}\right)$ and unemployment rate $\left(U N E M P_{h t}\right)$ are included as exogenous variables. Instruments validity is tested using a Sargan test of overidentifying restrictions and serial correlation tests ( $p$-values). The steady state denotes the long-term effect between the cost of capital and $L C^{\prime} / T A_{i t}$. All the variables are defined in Table 1. Columns (1) and (4) display the regression values for the whole sample, columns (2) and (5) for the periphery countries, and columns (3) and (6) for the core countries. Standard errors are in parenthesis and clustered at the bank level. Estimated followed by *,**, *** are statistically significant at the 10,5 and $1 \%$ level, respectively.

\begin{tabular}{|c|c|c|c|c|c|c|}
\hline & \multicolumn{3}{|c|}{$\begin{array}{l}\text { PANEL A: The whole period } \\
(2002 \mathrm{Q} 1-2016 \mathrm{Q} 4)\end{array}$} & \multicolumn{3}{|c|}{$\begin{array}{l}\text { PANEL B: The period after the crisis } \\
(2008 \mathrm{Q} 1-2016 \mathrm{Q} 4)\end{array}$} \\
\hline & Eurozone & $\begin{array}{l}\text { Periphery } \\
\text { Countries }\end{array}$ & $\begin{array}{c}\text { Core } \\
\text { Countries }\end{array}$ & Eurozone & $\begin{array}{l}\text { Periphery } \\
\text { Countries }\end{array}$ & $\begin{array}{c}\text { Core } \\
\text { Countries }\end{array}$ \\
\hline & $(1)$ & (2) & (3) & (4) & (5) & (6) \\
\hline$\left(L C^{\prime} /\right.$ & $0.463^{* * *}$ & $0.543^{* * *}$ & $0.421^{* * *}$ & $0.543^{* * *}$ & $0.613^{* * *}$ & $0.464^{* * *}$ \\
\hline$T A)_{\mathrm{it}-1}$ & $(0.113)$ & $(0.115)$ & $(0.104)$ & $(0.121)$ & $(0.132)$ & $(0.113)$ \\
\hline$r_{i t}$ & $\begin{array}{c}-0.143^{* * *} \\
(0.024)\end{array}$ & $\begin{array}{c}-0.183^{* * *} \\
(0.029)\end{array}$ & $\begin{array}{c}-0.134^{* * * *} \\
(0.021)\end{array}$ & $\begin{array}{c}-0.127^{* * * *} \\
(0.023)\end{array}$ & $\begin{array}{c}-0.153^{* * *} \\
(0.025)\end{array}$ & $\begin{array}{c}-0.117^{* * * *} \\
(0.022)\end{array}$ \\
\hline$r_{i t-1}$ & $\begin{array}{c}-0.082^{* * * *} \\
(0.015)\end{array}$ & $\begin{array}{c}-0.099^{* * * *} \\
(0.019)\end{array}$ & $\begin{array}{c}-0.065^{* * *} \\
(0.011)\end{array}$ & $\begin{array}{c}-0.085^{* * * *} \\
(0.013)\end{array}$ & $\begin{array}{c}-0.113^{* * *} \\
(0.023)\end{array}$ & $\begin{array}{c}-0.072^{* * *} \\
(0.021)\end{array}$ \\
\hline$L E V_{i t-1}$ & $\begin{array}{c}-0.053^{* * * *} \\
(0.013)\end{array}$ & $\begin{array}{c}-0.068^{* * * *} \\
(0.015)\end{array}$ & $\begin{array}{c}-0.041^{* * * *} \\
(0.011)\end{array}$ & $\begin{array}{c}-0.054^{* * * *} \\
(0.022)\end{array}$ & $\begin{array}{c}-0.078^{* * * *} \\
(0.023)\end{array}$ & $\begin{array}{l}-0.046^{* * *} \\
(0.020)\end{array}$ \\
\hline$r_{i t} \times L E V_{i t-}$ & $\begin{array}{c}-0.153^{* * *} \\
(0.035)\end{array}$ & $\begin{array}{c}-0.185^{* * *} \\
(0.032)\end{array}$ & $\begin{array}{c}-0.141^{* * *} \\
(0.032)\end{array}$ & $\begin{array}{c}-0.143^{* * *} \\
(0.021)\end{array}$ & $\begin{array}{c}-0.194^{* * *} \\
(0.026)\end{array}$ & $\begin{array}{c}-0.114^{* * *} \\
(0.021)\end{array}$ \\
\hline $\begin{array}{l}r_{i t-1} \quad \times \\
L E V_{i t-1}\end{array}$ & $\begin{array}{c}-0.093^{* * *} \\
(0.023)\end{array}$ & $\begin{array}{l}-0.114^{* * *} \\
(0.026)\end{array}$ & $\begin{array}{c}-0.078^{* * *} \\
(0.022)\end{array}$ & $\begin{array}{l}-0.104^{* * *} \\
(0.014)\end{array}$ & $\begin{array}{l}-0.116^{* * *} \\
(0.018)\end{array}$ & $\begin{array}{c}-0.093^{* * *} \\
(0.013)\end{array}$ \\
\hline Crisis $_{t}$ & $\begin{array}{l}-0.031^{* * *} \\
(0.005)\end{array}$ & $\begin{array}{l}-0.034^{* * *} \\
(0.005)\end{array}$ & $\begin{array}{l}-0.026^{* * * *} \\
(0.004)\end{array}$ & & & \\
\hline$C D S_{h t-1}$ & & & & $\begin{array}{c}-0.001^{* * *} \\
(0.000)\end{array}$ & $\begin{array}{c}-0.002^{* * *} \\
(0.000)\end{array}$ & $\begin{array}{c}-0.001^{* * *} \\
(0.000)\end{array}$ \\
\hline Intercept & $\begin{array}{l}0.231^{* * *} \\
(0.034)\end{array}$ & $\begin{array}{l}0.173^{* * *} \\
(0.037)\end{array}$ & $\begin{array}{l}0.285^{* * *} \\
(0.031)\end{array}$ & $\begin{array}{l}0.234^{* * *} \\
(0.045)\end{array}$ & $\begin{array}{l}0.193^{* *} \\
(0.046)\end{array}$ & $\begin{array}{l}0.283^{* * *} \\
(0.042)\end{array}$ \\
\hline$X_{i t-1}$ & Yes & Yes & Yes & Yes & Yes & Yes \\
\hline Bank FE & Yes & Yes & Yes & Yes & Yes & Yes \\
\hline Time FE & Yes & Yes & Yes & Yes & Yes & Yes \\
\hline $\begin{array}{l}\text { Steady } \\
\text { state }\end{array}$ & $\begin{array}{c}-0.419^{* * *} \\
(0.183)\end{array}$ & $\begin{array}{c}-0.617^{\text {**** }} \\
(0.239)\end{array}$ & $\begin{array}{c}-0.344^{\text {**** }} \\
(0.166)\end{array}$ & $\begin{array}{c}-0.464^{* * *} \\
(0.229)\end{array}$ & $\begin{array}{c}-0.687^{\text {**** }} \\
(0.326)\end{array}$ & $\begin{array}{c}-0.353^{\text {*** }} \\
(0.173)\end{array}$ \\
\hline$N$ & 1,134 & 682 & 452 & 451 & 279 & 172 \\
\hline $\begin{array}{l}\text { Sargan } \\
\text { test }\end{array}$ & 0.659 & 0.611 & 0.612 & 0.591 & 0.604 & 0.589 \\
\hline$A R(2)$ & 0.466 & 0.433 & 0.357 & 0.361 & 0.363 & 0.225 \\
\hline$A R(3)$ & 0.352 & 0.235 & 0.273 & 0.294 & 0.269 & 0.138 \\
\hline
\end{tabular}




\section{Table 10. Granger predictability test: Reverse causality}

This table provides the regression results of the Granger predictability test to study the reverse causality between the cost of capital $\left(r_{i t}\right)$ defined by investors' required return on bank equity computed as the return of the riskfree asset plus $\beta_{i t}$ times equity risk premium $\left(E R P_{t}\right)$, and the non-performing loans ratio $\left(N P L_{i t}\right)$ calculated as impaired loans over total loans, credit supply $\left(L O A N T A_{i t}\right)$ measured as customers' loans to total assets $\left(T A_{i t}\right)$ and liquidity creation $\left(L C_{i t} / T A_{i t}\right)$ computed as $0.5 \times$ (illiquid assets + liquid liabilities - liquid assets - illiquid liabilities - equity) over $T A_{i t}$. Quarterly observations for Eurozone listed banks are applied from 2002Q1 to 2016Q4 in all

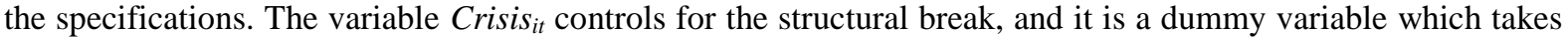
the value one after the beginning of the crisis $(t \geq 2007 \mathrm{Q} 3)$, and zero, otherwise. All the regressions are estimated using the Arellano and Bond's (1991) GMM. The set of instruments include $t-2, t-3$, and $t$-4 lagged variables. Instruments validity is tested using a Sargan test of overidentifying restrictions and serial correlation tests ( $p$ values). All the variables are defined in Table 1. Standard errors are in parenthesis and clustered at the bank level. Estimated followed by $*, * *, * *$ are statistically significant at the 10,5 and $1 \%$ level, respectively.

\begin{tabular}{|c|c|c|c|c|c|c|}
\hline & $\begin{array}{c}r_{i t} \\
(1)\end{array}$ & $\frac{N P L_{i t}}{(2)}$ & $\begin{array}{c}r_{i t} \\
(3)\end{array}$ & $\frac{L O A N T A_{i t}}{(4)}$ & $\begin{array}{c}r_{i t} \\
(5)\end{array}$ & $\frac{(L C / T A)_{\mathrm{it}}}{(6)}$ \\
\hline \multirow[t]{2}{*}{$y_{i t-1}$} & $0.749^{* * *}$ & 0.145 & $0.832^{* * *}$ & $-0.642^{* * *}$ & $0.770^{* * *}$ & $-0.821^{* * *}$ \\
\hline & $(0.113)$ & $(0.184)$ & $(0.127)$ & $(0.113)$ & $(0.083)$ & $(0.203)$ \\
\hline \multirow{2}{*}{$y_{i t-2}$} & $0.542^{* * *}$ & 0.131 & $0.524^{* * *}$ & $-0.558^{* * * *}$ & $0.435^{* * *}$ & $-0.612^{* * * *}$ \\
\hline & $(0.045)$ & $(0.256)$ & $(0.064)$ & $(0.130)$ & $(0.084)$ & $(0.131)$ \\
\hline \multirow[t]{2}{*}{$y_{i t-3}$} & $0.362^{* * *}$ & 0.032 & $0.236^{* * *}$ & $-0.425^{* *}$ & $0.231^{* * *}$ & $-0.421^{* *}$ \\
\hline & $(0.045)$ & $(0.065)$ & $(0.034)$ & $(0.211)$ & $(0.053)$ & $(0.143)$ \\
\hline \multirow[t]{2}{*}{$y_{i t-4}$} & $0.241^{\text {*** }}$ & 0.027 & $0.127^{* * *}$ & $-0.217^{* *}$ & $0.148^{* * *}$ & $-0.220^{* * * *}$ \\
\hline & $(0.024)$ & $(0.231)$ & $(0.053)$ & $(0.103)$ & $(0.041)$ & $(0.082)$ \\
\hline \multirow[t]{2}{*}{$N P L_{i t-1}$} & $0.135^{* *}$ & $0.542^{* * *}$ & & & & \\
\hline & $(0.057)$ & $(0.057)$ & & & & \\
\hline \multirow[t]{2}{*}{$N P L_{i t-2}$} & $0.081^{* * *}$ & $0.462^{* * *}$ & & & & \\
\hline & $(0.006)$ & $(0.037)$ & & & & \\
\hline \multirow[t]{2}{*}{$N P L_{i t-3}$} & $0.044^{*}$ & $0.327^{* * * *}$ & & & & \\
\hline & $(0.031)$ & $(0.015)$ & & & & \\
\hline \multirow{2}{*}{$N P L_{i t-4}$} & $0.021^{*}$ & $0.151^{* * *}$ & & & & \\
\hline & $(0.014)$ & $(0.024)$ & & & & \\
\hline \multirow[t]{2}{*}{$L_{O A N T A_{i t-1}}$} & & & -0.134 & $0.542^{* * *}$ & & \\
\hline & & & $(0.374)$ & $(0.074)$ & & \\
\hline \multirow[t]{2}{*}{$L O A N T A_{i t-2}$} & & & -0.085 & $0.335^{* * *}$ & & \\
\hline & & & $(0.237)$ & $(0.058)$ & & \\
\hline \multirow[t]{2}{*}{$L_{O A N T A_{i t-3}}$} & & & -0.073 & $0.164^{* * * *}$ & & \\
\hline & & & $(0.143)$ & $(0.023)$ & & \\
\hline \multirow{2}{*}{$L_{O A N T A_{i t-4}}$} & & & -0.042 & $0.099^{* * * *}$ & & \\
\hline & & & $(0.093)$ & $(0.021)$ & & \\
\hline \multirow[t]{2}{*}{$(L C / T A)_{\mathrm{it}-1}$} & & & & & -0.005 & $0.428^{* * *}$ \\
\hline & & & & & $(0.013)$ & $(0.064)$ \\
\hline \multirow[t]{2}{*}{$(L C / T A)_{\mathrm{it}-2}$} & & & & & -0.016 & $0.253^{* * *}$ \\
\hline & & & & & $(0.169)$ & $(0.079)$ \\
\hline \multirow[t]{2}{*}{$(L C / T A)_{\mathrm{it}-3}$} & & & & & -0.019 & $0.183^{* * * *}$ \\
\hline & & & & & $(0.084)$ & $(0.042)$ \\
\hline \multirow[t]{2}{*}{$(L C / T A)_{\mathrm{it}-4}$} & & & & & -0.011 & $0.121^{* * * *}$ \\
\hline & & & & & $(0.053)$ & $(0.040)$ \\
\hline \multirow[t]{2}{*}{ Crisist $_{t}$} & $0.010^{*}$ & $0.015^{* * *}$ & $0.064^{* * *}$ & $-0.115^{* * *}$ & $0.035^{* * *}$ & $-0.084^{* *}$ \\
\hline & $(0.006)$ & $(0.005)$ & $(0.011)$ & $(0.031)$ & $(0.008)$ & $(0.033)$ \\
\hline$N$ & 962 & 962 & 962 & 962 & 962 & 962 \\
\hline Sargan test & 0.685 & 0.487 & 0.582 & 0.518 & 0.357 & 0.664 \\
\hline$A R(2)$ & 0.392 & 0.240 & 0.472 & 0.641 & 0.893 & 0.550 \\
\hline$A R(3)$ & 0.288 & 0.148 & 0.272 & 0.445 & 0.646 & 0.217 \\
\hline
\end{tabular}




\section{Figures}

Figure 1. Evolution of the NPLs ratio, Beta CAPM, the cost of capital and the profitability gap in the periphery countries and the core countries before (2002Q1-2007Q2) and after (2007Q32016Q4) the crisis.

(a) Non-Performing Loans ratio $\left(N P L_{i t}\right)$

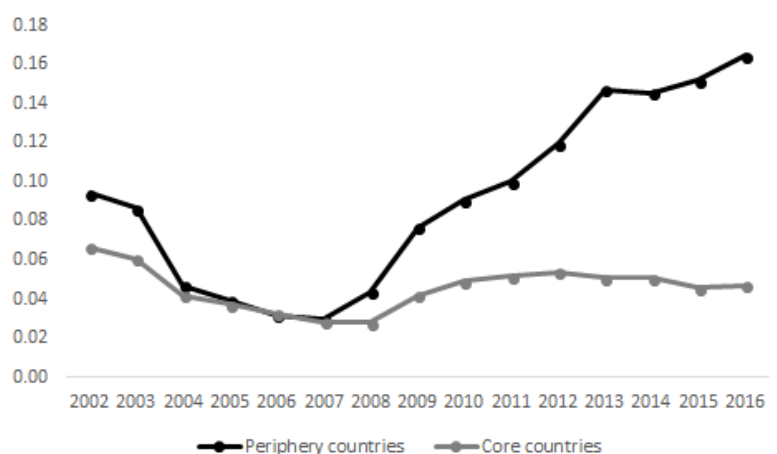

(c) Cost of capital $\left(r_{i t}\right)$

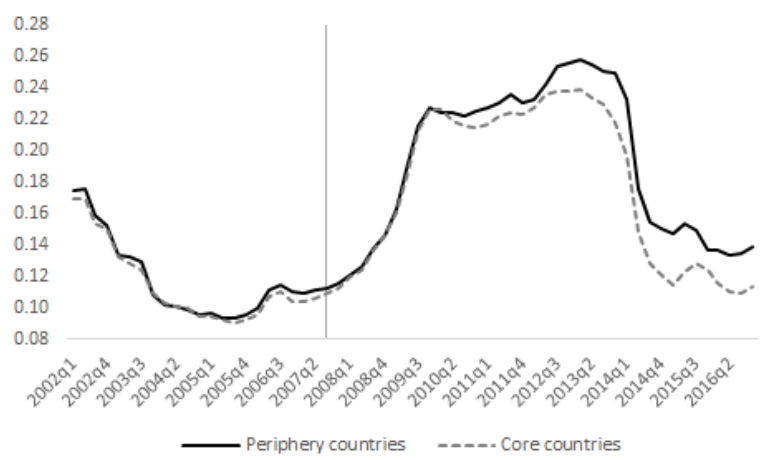

(b) Beta CAPM $\left(\beta_{i t}\right)$

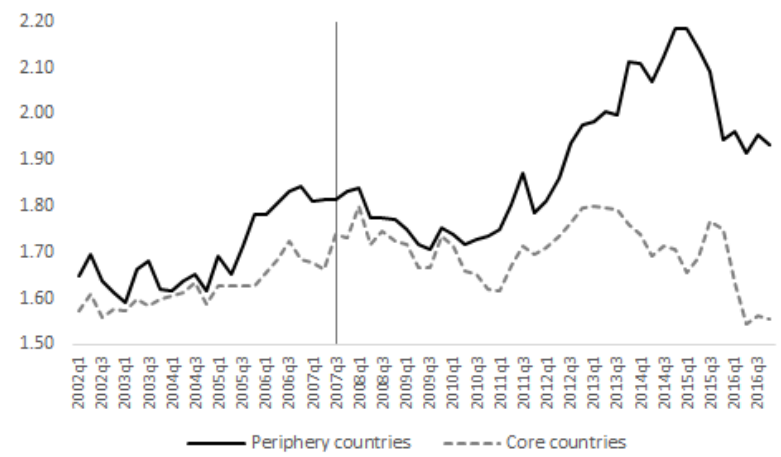

(d) Profitability gap $\left(r_{i t}-R O E_{i t}\right)$

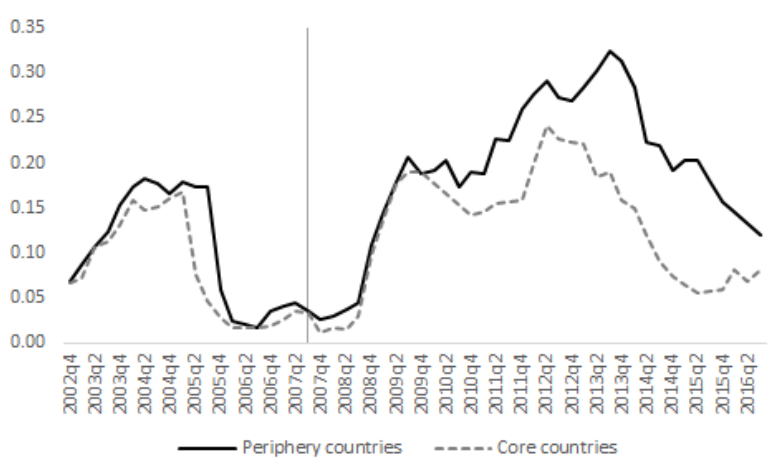

Source: Authors' estimation based on Thomson Reuters Datastream and Bankscope. The solid line represents the periphery countries, whilst the dashed line, the periphery countries. Subfigure (a) displays the evolution of the non-performing loans ratio $\left(N P L_{i t}\right)$ measured as the ration impaired loans to total loans, breaking the sample down before and after the crisis, and then by core and periphery countries. Subfigure (b) displays the evolution of the Beta CAPM $\left(\beta_{i t}\right)$ estimated as the covariance between the return of the stock $i$ and the return of the market portfolio over the variance of the market portfolio return, breaking the sample down before and after the crisis, and then by core and periphery countries. Subfigure (c) displays the evolution of the cost of capital $\left(r_{i t}\right)$ defined by investors' required return on bank equity computed as the return of the risk-free asset plus $\beta_{i t}$ times equity risk premium $\left(E R P_{t}\right)$, breaking the sample down before and after the crisis, and then by core and periphery countries. Subfigure (d) displays the evolution of the profitability gap $\left(r_{i t}-R O E_{i t}\right)$, the difference between investors' required return on bank equity, $r_{i t}$, and the return on bank equity $R O E_{i t}$, breaking the sample down before and after the crisis, and then by core and periphery countries. The vertical line splits the sample before and after the crisis periods $(t=2007 \mathrm{Q} 2)$. 
Figure 2. Distribution of the NPLs ratio, Beta CAPM, the cost of capital and the profitability gap in the periphery countries and the core countries before (2002Q1-2007Q2) and after (2007Q3-2016Q4) the crisis.

(a) Non-Performing Loans ratio $\left(N P L_{i t}\right)$

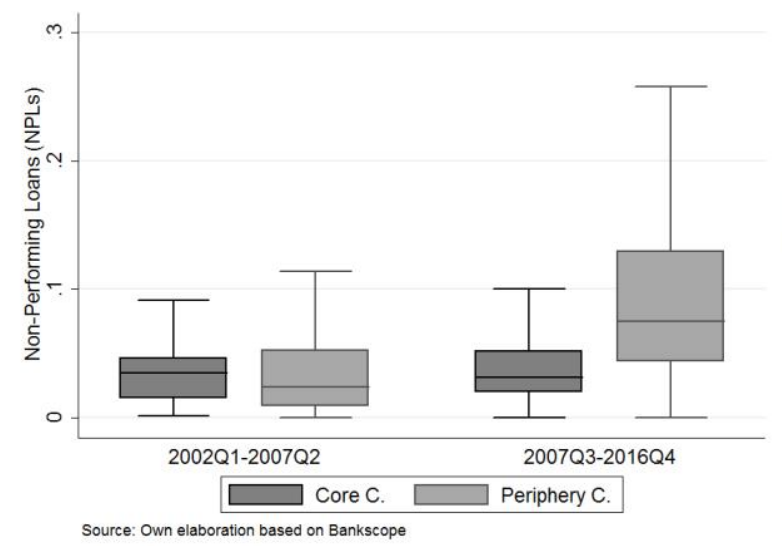

(c) Cost of capital $\left(r_{i t}\right)$

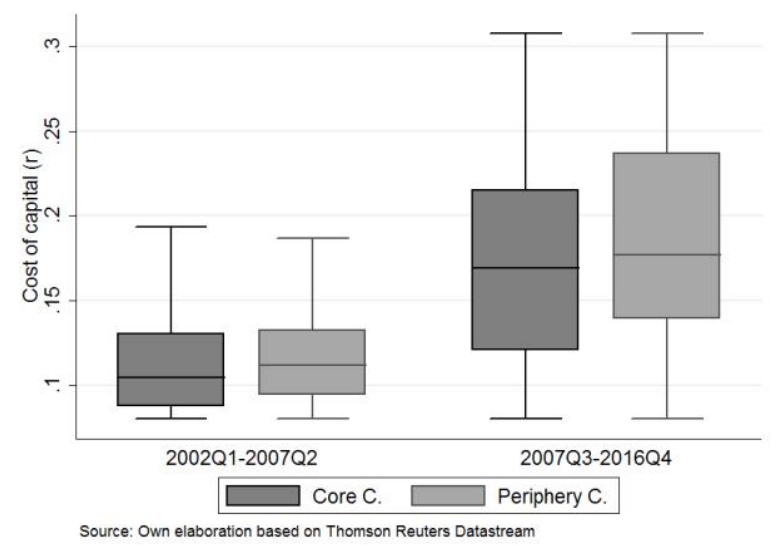

(b) Beta CAPM $\left(\beta_{i t}\right)$

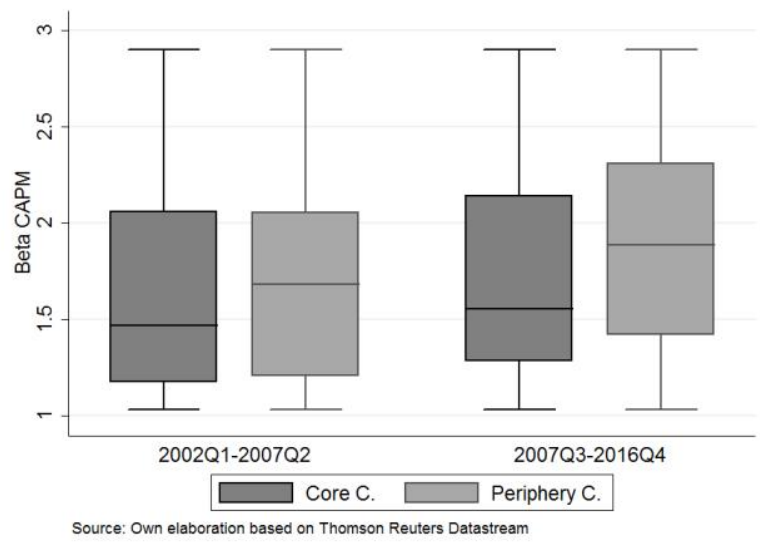

(d) Profitability gap $\left(r_{i t}-R O E_{i t}\right)$

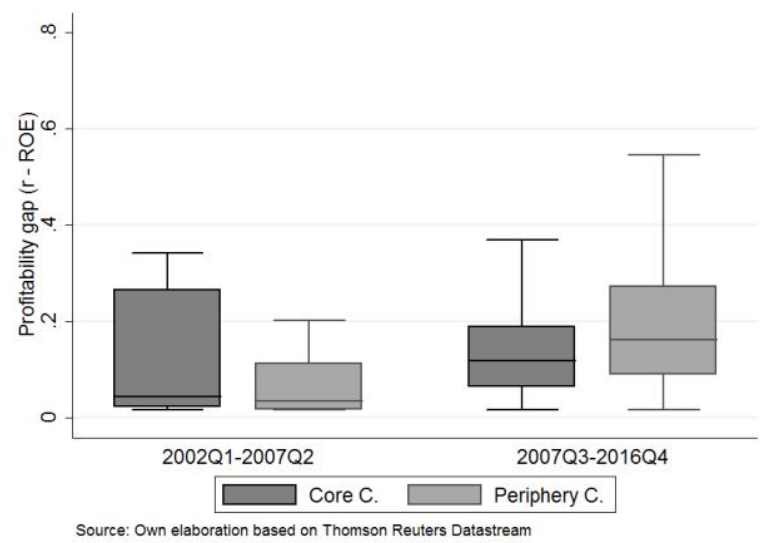

Source: Authors' estimation based on Thomson Reuters Datastream and Bankscope. The terms 'Core C'. and 'Periphery C.' refers to core countries and periphery countries, respectively. Subfigure (a) displays the distribution of the non-performing loans ratio $\left(N P L_{i t}\right)$ measured as the ration impaired loans to total loans, breaking the sample down before and after the crisis, and then by core and periphery countries. Subfigure (b) displays the distribution of the Beta CAPM $\left(\beta_{i t}\right)$ estimated as the covariance between the return of the stock $i$ and the return of the market portfolio over the variance of the market portfolio return, breaking the sample down before and after the crisis, and then by core and periphery countries. Subfigure (c) displays the distribution of the cost of capital $\left(r_{i t}\right)$ defined by investors' required return on bank equity computed as the return of the risk-free asset plus $\beta_{i t}$ times equity risk premium $\left(E R P_{t}\right)$, breaking the sample down before and after the crisis, and then by core and periphery countries. Subfigure (d) displays the distribution of the profitability gap $\left(r_{i t}-R O E_{i t}\right)$, the difference between investors' required return on bank equity, $r_{i t}$, and the return on bank equity $R O E_{i t}$, breaking the sample down before and after the crisis, and then by core and periphery countries. The whiskers represent the maximum and the minimum of the distribution. The box is divided into two parts by the median, i.e., the 50 percent of the distribution. The upper (lower) box represents the 25 percent of the sample greater (lower) than the median, i.e., the upper (lower) quartile. 


\section{Appendix A}

\section{A.1 Calculating bank market power: the Lerner index}

We use the Lerner index to control for the extent of competition in the European banking markets. The Lerner index measures the mark-up between the price and the marginal costs as a percentage of the price, thus indicating the degree of market power. The Lerner index ranges from zero to one (Lerner $i t \in(0,1)$ ); being Lerner $_{i t}=1$ in case of perfect monopoly, and Lerner $_{i t}=0$ in case of perfect competition, and exceptionally Lerner $_{i t}<0$ in case of nonoptimal behaviour. The Lerner index is calculated as follows:

$$
\text { Lerner }_{i t}=\frac{P_{i t}-M C_{i t}}{P_{i t}}
$$

where $P_{i t}$ is the ratio of interest income plus other operating income over total assets; and $M C_{i t}$ represents the marginal costs as presented in Appendix A.2.

\section{A.2 Calculating the marginal costs}

The computation of the marginal costs $\left(M C_{i t}\right)$ necessary to compute the Lerner index is based on the following transcendental logarithmic costs function (see Birchwood et al., 2017; Carbó et al., 2017):

$$
\begin{gathered}
\ln \left(C_{i t}\right)=\delta_{0}+\delta_{1} \ln \left(T A_{i t}\right)+\frac{\delta_{2}}{2}\left(\ln \left(T A_{i t}\right)\right)^{2}+\sum_{h=1}^{3} \phi_{h} \ln \left(w_{h i t}\right) \\
+\frac{1}{2} \sum_{h=1}^{3} \sum_{k=1}^{3} \phi_{h k} \ln \left(w_{h i t}\right) \times \ln \left(w_{k i t}\right)+\frac{1}{2} \sum_{h=1}^{3} \eta_{h} \ln \left(T A_{i t}\right) \times \ln \left(w_{\text {hit }}\right) \\
+\mu_{1} \text { Trend }+\mu_{2} \frac{1}{2} \text { Trend }{ }^{2}+\mu_{3} \text { Trend } \times \ln \left(T A_{i t}\right) \\
+\sum_{h=1}^{3} \kappa_{h} \text { Trend } \times \ln \left(w_{\text {hit }}\right)+\ln \left(u_{i t}\right)
\end{gathered}
$$

where $C_{i t}$ represents the total costs (including operating and financial costs), and $w_{i t}$ the costs of inputs (labour, capital, and deposits). The variable Trend is included to control for technological changes over time. A system factor (share) equations is derived according to the Shephard's lemma:

$$
\frac{\partial \ln \left(C_{i t}\right)}{\partial \ln \left(w_{h i t}\right)}=m_{h i t}=\phi_{h}+\frac{1}{2} \sum_{k=1}^{3} \phi_{k} \ln \left(w_{k i t}\right)+\frac{\eta_{h}}{2} \ln \left(T A_{i t}\right)+\kappa_{h} \text { Trend }
$$

being $m_{\text {hit }}$ the costs share of factor $h$ for bank $i$ in period $t$. 


\section{A.3 Liquidity classification of bank activities}

\begin{tabular}{|c|c|c|}
\hline \multicolumn{3}{|c|}{ Assets } \\
\hline Illiquid assets (weight $=1 / 2$ ) & Semiliquid assets (weight $=0$ ) & Liquid assets (weight $=-1 / 2$ ) \\
\hline Corporate commercial loans & Residential mortgage loans & Cash and due from banks \\
\hline Investment in properties & Other mortgage loans & Trading securities and at FV through income \\
\hline Foreclosed real estate & Other consumer / retail loans & Tradable derivatives \\
\hline Fixed assets & Loans and advances to banks & Available for sale securities \\
\hline Goodwill & Reverse repos and cash collateral & Held to maturity securities \\
\hline Other intangibles & & At-equity investment in associates \\
\hline Other assets & & Other securities \\
\hline \multicolumn{3}{|c|}{ Liabilities } \\
\hline Liquid liabilities (weight $=1 / 2$ ) & Semiliquid liabilities (weight $=0$ ) & Illiquid liabilities (weight $=-1 / 2$ ) \\
\hline Customer deposits-current & Customer deposits-term & Senior debt maturing after 1 year \\
\hline Customer deposits-savings & Deposits from banks & Subordinated borrowing \\
\hline Tradable derivatives & Repos and cash collateral & Other funding \\
\hline Trading liabilities & Other deposits and short-term borrowing & Credit impairment reserves \\
\hline & Fair value proportion of debt & Reserves for pensions and others \\
\hline & & Current tax liabilities \\
\hline & & Deferred tax liabilities \\
\hline & & Other deferred liabilities \\
\hline & & Other liabilities \\
\hline \multicolumn{3}{|c|}{ Off-balance-sheet activities } \\
\hline Illiquid activities (weight $=1 / 2$ ) & Semiliquid activities (weight $=0$ ) & Liquid activities (weight $=-1 / 2$ ) \\
\hline $\begin{array}{l}\text { Acceptances and documentary credits reported } \\
\text { Committed credit lines }\end{array}$ & $\begin{array}{l}\text { Managed securitized assets reported off-balance } \\
\text { sheet }\end{array}$ & \\
\hline Other contingent liabilities & $\begin{array}{l}\text { Other off-balance-sheet exposure to securitizations } \\
\text { Guarantees }\end{array}$ & \\
\hline \multicolumn{3}{|c|}{ Equity } \\
\hline & & Total equity (weight $=-1 / 2)$ \\
\hline & & Equity \\
\hline
\end{tabular}

All the variables are obtained from Bureau van Dijk Bankscope. 


\section{APPENDIX B: Testing the German banks for 'false positives' and 'false negatives'.}

Table B1. The effects of NPLs on the cost of capital for a subsample of German banks.

This table provides the regression results of the effects of NPLs on the cost of capital. The dependent variable is the cost of capital $\left(r_{i t}\right)$ defined by investors' required return on bank equity which is computed as the return of the risk-free asset plus $\beta_{i t}$ times equity risk premium $\left(E R P_{t}\right) . N P L_{i t}$ is measured as the ration impaired loans to total loans. Size $e_{i t}$ is the natural logarithm of one-period lagged total assets $\left(T A_{i t}\right) . L E V_{i t}$ is measured as total assets over total equity. Lerner ${ }_{i t}$ is computed as the price minus marginal costs over price. $\mathrm{INC}_{\mathrm{it}}$ is the non-interest income over total net income ratio. $E F F_{i t}$ is calculated as the operating costs over gross income ratio. The variable Crisis controls for the structural break, and it is a dummy variable which takes the value one after the beginning of the crisis ( $t \geq 2007 \mathrm{Q} 3)$, and zero, otherwise. $C D S_{h t}$ is the 10-years maturity sovereign Credit Default Swaps (CDS) at the country level $(h)$. Values for CDS are available from 2008Q1 to 2016Q4. All the specifications are estimated using the Arellano and Bond's (1991) GMM. The set of instruments includes $t-2, t-3$, and $t$-4 lagged variables. Economic growth $\left(G D P_{h t}\right)$ and unemployment rate $\left(U N E M P_{h t}\right)$ are included as exogenous variables. Instruments validity is tested using a Sargan test of overidentifying restrictions and serial correlation tests ( $p$-values). The steady state denotes the long-term effect between the cost of capital and the NPL ratio. Standard errors are in parenthesis and clustered at the bank level. Estimated followed by *,**,*** are statistically significant at the 10 , 5 and $1 \%$ level, respectively.

\begin{tabular}{|c|c|c|c|c|}
\hline & (1) & (2) & (3) & (4) \\
\hline$r_{i t-1}$ & $\begin{array}{c}0.432^{\text {**** }} \\
(0.103)\end{array}$ & $\begin{array}{c}0.435^{* * * *} \\
(0.102)\end{array}$ & $\begin{array}{c}0.464^{\text {**** }} \\
(0.103)\end{array}$ & $\begin{array}{c}0.474^{* * *} \\
(0.103)\end{array}$ \\
\hline$N P L_{i t}$ & $\begin{array}{c}0.053^{* * *} \\
(0.010)\end{array}$ & $\begin{array}{c}0.063^{* * * *} \\
(0.014)\end{array}$ & $\begin{array}{c}0.054^{* * *} \\
(0.013)\end{array}$ & $\begin{array}{c}0.056^{* * *} \\
(0.014)\end{array}$ \\
\hline$N P L_{i t-1}$ & $\begin{array}{l}0.034^{* *} \\
(0.011)\end{array}$ & $\begin{array}{l}0.043^{* *} \\
(0.019)\end{array}$ & $\begin{array}{c}0.032^{\text {**** }} \\
(0.013)\end{array}$ & $\begin{array}{c}0.042^{* * * *} \\
(0.018)\end{array}$ \\
\hline$L E V_{i t-I}$ & & $\begin{array}{c}0.146^{* * * *} \\
(0.064)\end{array}$ & & $\begin{array}{c}0.142^{* * * *} \\
(0.063)\end{array}$ \\
\hline$L O A N T A_{i t-1}$ & & $\begin{array}{l}-0.162^{* *} \\
(0.082)\end{array}$ & & $\begin{array}{c}-0.173^{* *} \\
(0.078)\end{array}$ \\
\hline Size $_{i t-1}$ & & $\begin{array}{c}0.124^{* * *} \\
(0.043)\end{array}$ & & $\begin{array}{c}0.120^{* * *} \\
(0.042)\end{array}$ \\
\hline Lerner $_{i t-1}$ & & $\begin{array}{c}0.121^{* * * *} \\
(0.035)\end{array}$ & & $\begin{array}{c}0.123^{* * * *} \\
(0.037)\end{array}$ \\
\hline$I N C_{i t-I}$ & & $\begin{array}{c}-0.112^{* * *} \\
(0.034)\end{array}$ & & $\begin{array}{c}-0.116^{\text {**** }} \\
(0.036)\end{array}$ \\
\hline$E F F_{i t-1}$ & & $\begin{array}{l}0.039^{* * *} \\
(0.012)\end{array}$ & & $\begin{array}{c}0.043^{* * *} \\
(0.014)\end{array}$ \\
\hline Crisis $_{t}$ & & $\begin{array}{c}0.014^{* * * *} \\
(0.006)\end{array}$ & & $\begin{array}{c}0.016^{* * *} \\
(0.005)\end{array}$ \\
\hline$C D S_{h t-1}$ & & & $\begin{array}{c}0.001^{\text {*** }} \\
(0.000)\end{array}$ & $\begin{array}{c}0.001^{\text {**** }} \\
(0.000)\end{array}$ \\
\hline Intercept & $\begin{array}{c}0.032^{\text {*** }} \\
(0.009)\end{array}$ & $\begin{array}{c}0.038^{* * *} \\
(0.008)\end{array}$ & $\begin{array}{l}0.039^{* * *} \\
(0.007)\end{array}$ & $\begin{array}{l}0.043^{* * *} \\
(0.009)\end{array}$ \\
\hline Steady state & $\begin{array}{c}0.153^{* * *} \\
(0.067)\end{array}$ & $\begin{array}{c}0.188^{* * *} \\
(0.085)\end{array}$ & $\begin{array}{c}0.160^{* * *} \\
(0.074)\end{array}$ & $\begin{array}{c}0.186^{* * * *} \\
(0.064)\end{array}$ \\
\hline$N$ & 185 & 185 & 115 & 115 \\
\hline Sargan test & 0.476 & 0.617 & 0.767 & 0.558 \\
\hline$A R(2)$ & 0.625 & 0.744 & 0.697 & 0.566 \\
\hline$A R(3)$ & 0.386 & 0.422 & 0.486 & 0.411 \\
\hline
\end{tabular}


Table B2. The effects of the cost of capital and on credit supply for a subsample of German banks.

This table provides the regression results of the effects of the cost of capital on credit supply. The dependent variable is the ratio loans to customers to total assets $\left(L O A N T A_{i t}\right)$, which is calculated as customers' loans over total assets $\left(T A_{i t}\right)$. The cost of capital $\left(r_{i t}\right)$ is investors' required return on bank equity computed as the return of the risk-free asset plus $\beta_{i t}$ times equity risk premium $\left(E R P_{t}\right) . S i z e_{i t}$ is the natural logarithm of one-period lagged total assets $\left(T A_{i t}\right) . L E V_{i t}$ is measured as total assets over total equity. Lerner ${ }_{i t}$ is computed as the price minus marginal costs over price. $\mathrm{INC}_{\mathrm{it}}$ is the non-interest income over total net income ratio. $E F F_{i t}$ is calculated as the operating costs over gross income ratio. The variable Crisis $_{t}$ controls for the structural break, and it is a dummy variable which takes the value one after the beginning of the crisis $(t \geq 2007 \mathrm{Q} 3)$, and zero, otherwise. $C D S_{h t}$ is the 10 -years maturity sovereign Credit Default Swaps (CDS) at the country level $(h)$. Values for CDS are available from 2008Q1 to 2016Q4. All the specifications are estimated using the Arellano and Bond's (1991) GMM. The set of instruments includes $t-2, t-3$, and $t-4$ lagged variables. Economic growth $\left(G D P_{h t}\right)$ and unemployment rate $\left(U N E M P_{h t}\right)$ are included as exogenous variables. Instruments validity is tested using a Sargan test of overidentifying restrictions and serial correlation tests ( $p$-values). The steady state denotes the long-term effect between $L O A N T A_{i t}$ and the cost of capital and the profitability gap, respectively. All the variables are defined in Table1. Standard errors are in parenthesis and clustered at the bank level. Estimated followed by $*, * *, * * *$ are statistically significant at the 10,5 and $1 \%$ level, respectively.

\begin{tabular}{|c|c|c|c|c|}
\hline & (1) & (2) & (3) & (4) \\
\hline LOANTA $_{i t-1}$ & $\begin{array}{c}0.353^{* * *} \\
(0.115)\end{array}$ & $\begin{array}{l}0.331^{* * *} \\
(0.113)\end{array}$ & $\begin{array}{c}0.364^{* * *} \\
(0.113)\end{array}$ & $\begin{array}{c}0.385^{* * *} \\
(0.114)\end{array}$ \\
\hline$r_{i t}$ & $\begin{array}{c}-0.083^{* * * *} \\
(0.015)\end{array}$ & $\begin{array}{c}-0.073^{* * *} \\
(0.014)\end{array}$ & $\begin{array}{c}-0.083^{* * *} \\
(0.017)\end{array}$ & $\begin{array}{c}-0.075^{\text {**** }} \\
(0.015)\end{array}$ \\
\hline$r_{i t-1}$ & $\begin{array}{c}-0.053^{* * * *} \\
(0.013)\end{array}$ & $\begin{array}{c}-0.049^{* * * *} \\
(0.012)\end{array}$ & $\begin{array}{c}-0.056^{* * * *} \\
(0.015)\end{array}$ & $\begin{array}{c}-0.046^{* * * *} \\
(0.011)\end{array}$ \\
\hline$L E V_{i t-1}$ & $\begin{array}{c}-0.105^{* * *} \\
(0.024)\end{array}$ & $\begin{array}{c}-0.109^{* * * *} \\
(0.026)\end{array}$ & $\begin{array}{c}-0.095^{* * *} \\
(0.019)\end{array}$ & $\begin{array}{c}-0.103^{* * * *} \\
(0.018)\end{array}$ \\
\hline$r_{i t} \times L E V_{i t-1}$ & & $\begin{array}{c}-0.134^{* * * *} \\
(0.028)\end{array}$ & & $\begin{array}{c}-0.123^{\text {**** }} \\
(0.026)\end{array}$ \\
\hline$r_{i t-1} \times L E V_{i t-1}$ & & $\begin{array}{c}-0.121^{* * * *} \\
(0.015)\end{array}$ & & $\begin{array}{c}-0.124^{* * * *} \\
(0.018)\end{array}$ \\
\hline$S i z e_{i t-1}$ & $\begin{array}{c}-0.363^{* * *} \\
(0.124)\end{array}$ & $\begin{array}{c}-0.353^{* * *} \\
(0.121)\end{array}$ & $\begin{array}{c}-0.346^{* * *} \\
(0.123)\end{array}$ & $\begin{array}{c}-0.352^{* * * *} \\
(0.127)\end{array}$ \\
\hline Lerner $_{i t-1}$ & $\begin{array}{c}-0.013^{* * *} \\
(0.006)\end{array}$ & $\begin{array}{c}-0.012^{* * * *} \\
(0.006)\end{array}$ & $\begin{array}{c}-0.015^{* * *} \\
(0.007)\end{array}$ & $\begin{array}{c}-0.013^{* * * *} \\
(0.006)\end{array}$ \\
\hline$I N C_{i t-1}$ & $\begin{array}{c}-0.141^{* * *} \\
(0.022)\end{array}$ & $\begin{array}{c}-0.134^{* * * *} \\
(0.020)\end{array}$ & $\begin{array}{c}-0.132^{* * * *} \\
(0.021)\end{array}$ & $\begin{array}{c}-0.131^{* * * *} \\
(0.022)\end{array}$ \\
\hline$E F F_{i t-1}$ & $\begin{array}{c}-0.063^{* * *} \\
(0.021)\end{array}$ & $\begin{array}{c}-0.054^{* * * *} \\
(0.018)\end{array}$ & $\begin{array}{c}-0.065^{* * *} \\
(0.020)\end{array}$ & $\begin{array}{c}-0.068^{* * * *} \\
(0.018)\end{array}$ \\
\hline Crisis $_{t}$ & $\begin{array}{c}-0.214^{* * *} \\
(0.037)\end{array}$ & $\begin{array}{c}-0.232^{* * * *} \\
(0.042)\end{array}$ & & \\
\hline$C D S_{h t-1}$ & & & $\begin{array}{c}-0.001^{* * *} \\
(0.000)\end{array}$ & $\begin{array}{c}-0.001^{* * *} \\
(0.000)\end{array}$ \\
\hline Intercept & $\begin{array}{c}0.215^{* * *} \\
(0.060)\end{array}$ & $\begin{array}{c}0.217^{* * * *} \\
(0.056)\end{array}$ & $\begin{array}{c}0.205^{* * * *} \\
(0.053)\end{array}$ & $\begin{array}{c}0.201^{* * *} \\
(0.053)\end{array}$ \\
\hline Steady state & $\begin{array}{c}-0.210^{* * * *} \\
(0.073) \\
\end{array}$ & $\begin{array}{c}-0.182^{* * * *} \\
(0.084)\end{array}$ & $\begin{array}{c}-0.219^{* * * *} \\
(0.078)\end{array}$ & $\begin{array}{c}-0.197^{* * *} \\
(0.082)\end{array}$ \\
\hline$N$ & 185 & 185 & 115 & 115 \\
\hline Sargan test & 0.632 & 0.782 & 0.797 & 0.691 \\
\hline$A R(2)$ & 0.501 & 0.620 & 0.596 & 0.624 \\
\hline$A R(3)$ & 0.244 & 0.294 & 0.230 & 0.203 \\
\hline
\end{tabular}


Table B3. The effects of the cost of capital on liquidity creation for a subsample of German banks.

This table provides the regression results of the effects of the cost of capital $\left(r_{i t}\right)$ on liquidity creation. The dependent variable is the ratio liquidity creation to total assets $\left(L C_{i t} / T A_{i t}\right)$, which is calculated as $0.5 \times$ (illiquid assets + liquid liabilities - liquid assets - illiquid liabilities - equity) over total assets $\left(T A_{i t}\right)$. ). The cost of capital $\left(r_{i t}\right)$ is investors' required return on bank equity computed as the return of the risk-free asset plus $\beta_{i t}$ times equity risk premium $\left(E R P_{t}\right)$. Size $e_{i t}$ is the natural logarithm of one-period lagged total assets $\left(T A_{i t}\right) . L E V_{i t}$ is measured as total assets over total equity. Lerner ${ }_{i t}$ is computed as the price minus marginal costs over price. $I N C_{i t}$ is the noninterest income over total net income ratio. $E F F_{i t}$ is calculated as the operating costs over gross income ratio. The variable Crisis $t_{t}$ controls for the structural break, and it is a dummy variable which takes the value one after the beginning of the crisis ( $t \geq 2007 \mathrm{Q} 3$ ), and zero, otherwise. $C D S_{h t}$ is the 10-years maturity sovereign Credit Default Swaps (CDS) at the country level $(h)$. Values for CDS are available from 2008Q1 to 2016Q4. All the specifications are estimated using the Arellano and Bond's (1991) GMM. The set of instruments includes $t-2, t-3$, and $t-4$ lagged variables. Economic growth $\left(G D P_{h t}\right)$ and unemployment rate $\left(U N E M P_{h t}\right)$ are included as exogenous variables. Instruments validity is tested using a Sargan test of overidentifying restrictions and serial correlation tests ( $p$ values). The steady state denotes the long-term effect between $L C_{i t} / T A_{i t}$ and the cost of capital and the profitability gap, respectively. All the variables are defined in Table1. Standard errors are in parenthesis and clustered at the bank level. Estimated followed by $* * *, * * *$ are statistically significant at the 10,5 and $1 \%$ level, respectively.

\begin{tabular}{|c|c|c|c|c|}
\hline & (1) & $(2)$ & (3) & (4) \\
\hline$(L C / T A)_{i t-1}$ & $\begin{array}{c}0.375^{* * *} \\
(0.063)\end{array}$ & $\begin{array}{c}0.356^{* * * *} \\
(0.067)\end{array}$ & $\begin{array}{c}0.376^{* * *} \\
(0.073)\end{array}$ & $\begin{array}{c}0.363^{* * *} \\
(0.065)\end{array}$ \\
\hline$r_{i t}$ & $\begin{array}{c}-0.122^{* * * *} \\
(0.025)\end{array}$ & $\begin{array}{c}-0.121^{* * *} \\
(0.024)\end{array}$ & $\begin{array}{c}-0.123^{* * *} \\
(0.024)\end{array}$ & $\begin{array}{c}-0.123^{* * *} \\
(0.028)\end{array}$ \\
\hline$r_{i t-1}$ & $\begin{array}{c}-0.082^{* * * *} \\
(0.021)\end{array}$ & $\begin{array}{c}-0.083^{* * * *} \\
(0.026)\end{array}$ & $\begin{array}{c}-0.084^{* * *} \\
(0.023)\end{array}$ & $\begin{array}{c}-0.081^{* * *} \\
(0.024)\end{array}$ \\
\hline$L E V_{i t-1}$ & $\begin{array}{c}-0.048^{* * *} \\
(0.019)\end{array}$ & $\begin{array}{c}-0.052^{* * *} \\
(0.019)\end{array}$ & $\begin{array}{c}-0.052^{* * *} \\
(0.016)\end{array}$ & $\begin{array}{c}-0.053^{* *} \\
(0.018)\end{array}$ \\
\hline$r_{i t} \times L E V_{i t-1}$ & & $\begin{array}{c}-0.153^{* * * *} \\
(0.036)\end{array}$ & & $\begin{array}{c}-0.156^{* * * *} \\
(0.038)\end{array}$ \\
\hline$r_{i t-I} \times L E V_{i t-I}$ & & $\begin{array}{c}-0.112^{* * * *} \\
(0.040)\end{array}$ & & $\begin{array}{c}-0.110^{* * * *} \\
(0.042)\end{array}$ \\
\hline$L_{O A N T A} A_{i t}$ & $\begin{array}{c}0.264^{* * *} \\
(0.023)\end{array}$ & $\begin{array}{c}0.259^{\text {**** }} \\
(0.029)\end{array}$ & $\begin{array}{c}0.2452^{\text {*** }} \\
(0.023)\end{array}$ & $\begin{array}{c}0.246^{* * * *} \\
(0.022)\end{array}$ \\
\hline Size $_{i t-1}$ & $\begin{array}{l}0.130^{* * *} \\
(0.021)\end{array}$ & $\begin{array}{c}0.123^{* * *} \\
(0.018)\end{array}$ & $\begin{array}{l}0.131^{\text {*** }} \\
(0.020)\end{array}$ & $\begin{array}{l}0.126^{* * *} \\
(0.017)\end{array}$ \\
\hline Lerner $_{i t-1}$ & $\begin{array}{c}0.012^{* * * *} \\
(0.007)\end{array}$ & $\begin{array}{c}0.010^{* * *} \\
(0.006)\end{array}$ & $\begin{array}{c}0.014^{* * * *} \\
(0.005)\end{array}$ & $\begin{array}{c}0.011^{* * *} \\
(0.005)\end{array}$ \\
\hline$I N C_{i t-1}$ & $\begin{array}{c}0.122^{* * * *} \\
(0.017)\end{array}$ & $\begin{array}{c}0.117^{\text {***** }} \\
(0.014)\end{array}$ & $\begin{array}{c}0.122^{\text {**** }} \\
(0.016)\end{array}$ & $\begin{array}{c}0.116^{* * * *} \\
(0.014)\end{array}$ \\
\hline$E F F_{i t-1}$ & $\begin{array}{c}-0.026^{* * *} \\
(0.014)\end{array}$ & $\begin{array}{c}-0.025^{* *} \\
(0.012)\end{array}$ & $\begin{array}{c}-0.025^{* *} \\
(0.013)\end{array}$ & $\begin{array}{c}-0.024^{* * * *} \\
(0.012)\end{array}$ \\
\hline Crisis $_{t}$ & $\begin{array}{c}-0.031^{* * * *} \\
(0.011)\end{array}$ & $\begin{array}{c}-0.026^{* * *} \\
(0.009)\end{array}$ & $\begin{array}{c}-0.034^{* * *} \\
(0.012)\end{array}$ & $\begin{array}{c}-0.025^{* * * *} \\
(0.008)\end{array}$ \\
\hline$C D S_{h t-1}$ & & & $\begin{array}{c}-0.001^{* * *} \\
(0.000)\end{array}$ & $\begin{array}{c}-0.001^{* * *} \\
(0.000)\end{array}$ \\
\hline Intercept & $\begin{array}{c}0.330^{* * *} \\
(0.034)\end{array}$ & $\begin{array}{c}0.323^{* * *} \\
(0.032)\end{array}$ & $\begin{array}{l}0.334^{* * *} \\
(0.037)\end{array}$ & $\begin{array}{c}0.321^{* * *} \\
(0.031)\end{array}$ \\
\hline Steady state & $\begin{array}{c}-0.326^{\text {*** }} \\
(0.148) \\
\end{array}$ & $\begin{array}{c}-0.317^{* * *} \\
(0.153) \\
\end{array}$ & $\begin{array}{c}-0.332^{* * *} \\
(0.142) \\
\end{array}$ & $\begin{array}{c}-0.320^{* * *} \\
(0.152)\end{array}$ \\
\hline$N$ & 185 & 185 & 115 & 115 \\
\hline Sargan test & 0.525 & 0.630 & 0.585 & 0.610 \\
\hline$A R(2)$ & 0.501 & 0.472 & 0.489 & 0.431 \\
\hline$A R(3)$ & 0.302 & 0.303 & 0.333 & 0.294 \\
\hline
\end{tabular}




\section{References}

Accornero, M., Alessandri, P., Carpinelli, L., Sorrentino, A.M., 2017. Non-performing loans and the supply of bank credit: Evidence from Italy. Bank of Italy, Occasional Paper No. 374.

Adrian, T., Friedman, E., Muir, T., 2015. The cost of capital of the financial sector. Federal Reserve Bank of New York Staff Reports No. 755.

Adrian, T., Shin, H.S., 2010. Liquidity and Leverage. J. Financ. Intermed. 19, 418-437.

Altavilla, C., Pagano, M., Simonelli, S., 2016. Bank exposures and sovereign stress transmission. European Systemic Risk Board. Working Paper Series No. 11 / May 2016.

Anastasiou, D., Louri, H., Tsionas, E.G., 2017. Non-Performing Loans in the Euro Area: Are Core-Periphery Banking Markets Fragmented? SSRN Working Paper. Available at: https://papers.ssrn.com/sol3/papers.cfm?abstract id=2868777

Angelini, P., Bofondi, M., Sette, E., Zingales, L., 2017. The origins of the Italian NPLs. Mimeo.

Avgouleas, E., Goodhart, C., 2015. Critical reflections on bail-ins. Journal of Financial Regulation 1, 3-29.

Avgouleas, E., Goodhart, C., 2016. An anatomy of bank bail-ins - Why the Eurozone needs a fiscal backstop for the banking sector. European Economy - Banks, Regulation, and the Real Sector 2016.2, 75-90.

Balgova, M., Nies, M., Plekhanov, A., 2016. The economic impact of reducing nonperforming loans. EBRD Working Paper No. 193, European Bank for Reconstruction and Development, London.

Bank for International Settlements (BIS), 2005. Credit Risk Transfer. Basel Committee on Banking Supervision - The Joint Forum. Basel.

Barba Navaretti, G., Calzolari, G., Pozzolo, A.F., 2016. Diabolic loop or incomplete union? Sovereign and banking risk. European Economy - Banks, Regulation, and the Real Sector 2016.1, 9-28.

Bending, T., Berndt, M., Brutscher, P., Nelvin, O., Revoltella, D., Slacik, T., Wolski, M., 2014. Unlocking lending in Europe. European Investment Bank. Available at: http://www.eib.org/infocentre/publications/all/unlocking-lending-in-europe.htm

Berger, A.N., Bouwman, C.H.S., 2009. Bank liquidity creation. Rev. Financ. Stud. 22, 3779-3837.

Berger, A.N., Bouwman, C.H.S., 2013. How does capital affect bank performance during financial crises? J. Financ. Econ. 109, 146-176.

Berger, A. N., DeYoung, R., 1997. Problem Loans and Cost Efficiency in Commercial Banks. J. Bank Financ. 21, 849-870.

Berger, A., Imbierowicz, B., Rauch, C., 2016. The roles of corporate governance in bank failures during the recent financial crisis. J. Money Credit Bank. 48, 729-770.

Bernanke, B., Gelter, M., 1986. Banking and macroeconomic equilibrium. Princeton University. Woodrow Wilson School of Public and International Affairs.

Betz, F., Hautsch, N., Peltonen, T.A., Schienle, M., 2016. Systemic risk spillovers in the European banking and sovereign network. J. Financ. Stab. 25, 206-224.

Bowman, C.H.S., Malmendier, U., 2015. Does a bank’s history affect its risk taking? Am. Econ. Rev. 105, 321325.

Brunnermeier, M. K., Garicano, L., Lane, P., Pagano, M., Reis, R., Santos, T., Thesmar, D., Van Nieuwerburgh, S., Vayanos, D., 2011. European Safe Bonds (ESBies). The Euronomics Group.

Buch, C., Koetter, M., Ohls, J., 2016. Banks and sovereign risk: A granular view. J. Financ. Stab. 25, 1-15.

Buchner, A., Wagner, N., 2017. Rewarding risk-taking or skills? The case of private equity fund managers. J. Bank Financ. 80, 14-32. 
Caballero, R.J., Hoshi, T., Kashyap, A.K., 2008. Zombie lending and depressed restructuring in Japan. Am. Econ. Rev. 98, 1943-1977.

Cai, J., Eidam, F., Saunders, A., Steffen, S., 2018. Syndication, interconnectedness, and systemic risk. J. Financ. Stab. 34, 105-120.

Calomiris, C.W., Jaremski, M., 2016. Deposit insurance: Theories and facts. NBER Working Papers Series 22223. Available at: http://www.nber.org/papers/w22223.pdf

Caprio, G., Summers, L.H., 1993. Finance and its reform: Beyond laissez-faire. Policy Research Working Paper No. 1993/08/31 WPS1171.

Carbó-Valverde, S., Mansilla-Fernández, J.M., Rodríguez-Fernández, F., 2017. The effects of bank market power in the short-term and the long-term firm credit availability and investment. Span. J. Financ. Account. 46, 127.

Caporin, M., Pelizzon, L., Ravazzolo, F., Rigobon, R., 2018. Measuring sovereign contagion in Europe. J. Financ. Stab., forthcoming.

Cucinelli, D., 2015. The Impact of Non-Performing Loans on Bank Lending Behaviour: Evidence from the Italian Banking Sector. Eurasian J. Bus. Econ. 8, 59-71.

Dagher, J., Dell'Ariccia, G., Laeven, L., Ratnovski, L., Tong, H., 2014. Benefits and Costs of Bank Capital, IMF Staff Discussion Note, 16/04.

Dickey, D.A., Fuller, W.A., 1981. Likelihood ratio Statistics for Autorregressive Time Series with a Unit Root. Econometrica 49, 1057-1072.

Dickey, D.A., Fuller, W.A., 1979. Distribution of the Estimators for Autorregressive Time Series with a Unit Root. J. Am. Stat. Assoc. 74, 427-431.

Eisdorfer, A., 2008. Empirical evidence of risk shifting in financially distressed banks. J. Financ. 63, 609-637.

Engler, P., Große Steffen, C., 2016. Sovereign risk, interbank freezes, and aggregate fluctuations. Eur. Econ. Rev. $87,34-61$.

European Systemic Risk Board (2017). Resolving non-performing loans in Europe. July 2017. Available at: https://www.esrb.europa.eu/pub/pdf/reports/20170711 resolving npl report.en.pdf

Fama, E. F., MacBeth, J. D., 1973. Risk, return and equilibrium: empirical tests. J. Polit. Econ. 81, 607-636.

Fu, X.M., Lin, Y.R., Molyneux, P., 2014. Bank competition and financial stability in Asia Pacific. J. Bank Financ. $38,64-77$.

Gennaioli, N., Martin, A., Rossi, S., 2014. Sovereign default, domestic banks, and financial institutions. J. Financ. 69, 819-866.

Ghosh, A., 2017. Sector-specific analysis of non-performing loans in the US banking system and their macroeconomic impact. J. Econ. Bus. 93, 29-45.

Holtz-Eakin, D., Newey, W., Rosen, H., 1988. Estimating Vectors Autoregressions with Panel Data. Econometrica, 56, 1371-1395.

Johansen, S., 1988. Statistical analysis of cointegration vectors. J. Econ. Dyn. Control. 12 (2-3), 231-254.

Kaminsky, G.L., Reinhart, C.M., 1999. The twin crises: The causes of banking and balance-of-payments problems. Am. Econ. Rev. 89, 473-500.

Keenan, S., 2000. Historical default rates of corporate bond issuers 1920-1990. Moody’s Special Report.

King, M., 2009. The cost of equity of global banks: a CAPM perspective from 1990 to 2009. BIS Quarterly Review. September 2009. Available at: https://www.bis.org/publ/qtrpdf/r qt0909g.htm

Koudstaal, M., Wijnbergen, S., 2012. On risk, leverage and banks: Do highly leveraged banks take on excessive risk? Tinbergen Institute Discussion Paper. Available at: http://papers.tinbergen.nl/12022.pdf 
Lanotte, M., Manzelli, G., Rinaldi, A.M., Taboga, M., Tommasino, P., 2016. Easier said than done? Reforming the prudential treatment of banks' sovereign exposures. European Economy - Banks, Regulation, and the Real Sector, 2016.1, 73-103.

Lakdawala, A., Minetti, R., Olivero, M.P., 2017. Interbank markets and credit policies amid a sovereign debt crisis. Mimeo. Available at: https://aeimit.weebly.com/uploads/2/5/5/8/25585085/interbank.pdf

Li, J., Zinna, G., 2014. How much of bank credit risk is sovereign risk? Evidence from the Eurozone. Bank of Italy Working Papers No 990.

Louzis, D.P., Vouldis, A.T., Metaxas, V.L., 2012. Macroeconomic and bank-specific determinants of nonperforming loans in Greece: A comparative study of mortgage, business and consumer loan portfolios. J. Bank Financ. 36, 1012-1027.

Maddala, G.S., Wu, S., 1999. A Comparative Study of Unit Root Tests with Panel Data and a New Simple Test. Oxf. Bull. Econ. Stat. 61, 631-652.

Mansilla-Fernández, J.M., 2017. Numbers. European Economy - Banks, Regulation, and the Real Sector 2017.1, 31-38.

Paltalidis, N., Gounopoulos, D., Kizys, R., Koutelidakis, Y., 2015. Transmission channels of systemic risk and contagion in the European financial network. J. Bank Financ. 61, supplement 1, S36-S52.

Paniagua, J., Sapena, J., Tamarit, C., 2017. Sovereign debt spreads in EMU: The time-varying role of fundamentals and market distrust. J. Financ. Stab., 33, 187-206.

Peek, J., Rosengren, E.S., 1995. Collateral damage: Effects of the Japanese banks bank crisis on real activity in the United States. Am. Econ. Rev. 90, 30-45.

Perron, P., 1989. The great crash, the oil price shock and the unit root hypothesis. Econometrica, 57, 1361-1401.

Podstawski, M., Velinov, A., 2018. The state dependent impact of bank exposure on sovereign risk. J. Bank Financ. 88, 63-75.

Reusens, P, Croux, C., 2017. Sovereign credit rating determinants: A comparison before and after the European debt crisis. J. Bank Financ. 77, 108-121.

Schivardi, F., Sette, F., Tabellini, G., 2017. Credit misallocation during the European financial crisis. Bank of Italy working paper n. 1139. Available at: https://papers.ssrn.com/sol3/papers.cfm?abstract_id=3051189

Salas, V., Saurina, J., 2002. Credit risk in two institutional regimes: Spanish commercial and savings banks. J. Financ. Serv. Res. 22, 203-224.

Stern, G., Feldman, R., 2004. Too big to fail: The hazard of banks bailouts. The Brookings Institution, Washington, DC.

Van den Heuvel, S.J., 2008. The welfare cost of bank capital requirements. J. Monetary Econ. 55, 2, 298-320.

Zhang, D., Cai, J., Dickinson, D.G., Kutan, A.M., 2016. Non-performing loans, moral hazard and regulation of the Chinese commercial banking system. J. Bank Financ. 63, 48-60. 


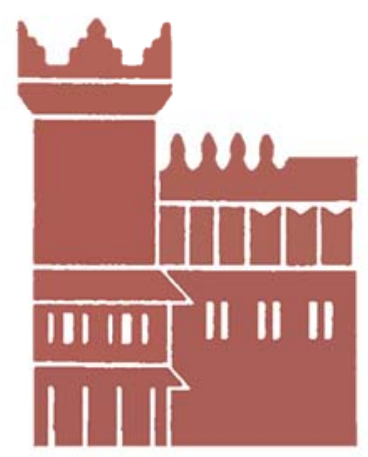

Alma Mater Studiorum - Università di Bologna DEPARTMENT OF ECONOMICS

Strada Maggiore 45

40125 Bologna - Italy

Tel. +39051 2092604

Fax +390512092664

http://www.dse.unibo.it 